\title{
Surface-applied or incorporated biochar and compost combination improves soil fertility, Chinese cabbage and papaya biomass
}

\author{
Justine $\operatorname{Cox}^{1,2}$ (D) Nguyen V. Hue $^{1}$ (D) Amjad Ahmad ${ }^{1} \cdot$ Kent D. Kobayashi $^{1}$
}

Received: 27 May 2020 / Accepted: 5 December 2020 / Published online: 29 January 2021

(c) The Author(s) 2021

\begin{abstract}
Many Hawaiian agricultural soils are acidic with low-nutrient retention; therefore, organic soil amendments are often used to improve soil properties and increase yields. Amendments can be incorporated for annual crops, but perennial orchards need surface application to avoid damaging surface roots. Pot trials compared responses to incorporated (IBC) or surface-applied (SBC) combination of hardwood biochar and chicken manure compost (4\% v/v of each amendment) added to an Andisol and Oxisol. Soil $\mathrm{pH}$ was increased by $0.4-1.1$ units in IBC and by $0.2-0.5$ for SBC in the $0-10 \mathrm{~cm}$ soil layer. Both SBC and IBC increased soil total $\mathrm{N}$, extractable $\mathrm{P}, \mathrm{Ca}$ and $\mathrm{Mg}$ in the $0-10 \mathrm{~cm}$ soil layer. Soil $\mathrm{pH}$, total $\mathrm{C}$ and extractable $\mathrm{Ca}$ were also higher in the 10-20 cm soil layer for IBC soil, indicating movement and/or leaching of amendments. Chinese cabbage biomass was 18-70\% higher in the IBC and 14-47\% higher in the SBC than that in the unamended soil, while papaya biomass was $23 \%$ and $19 \%$ higher in SBC and IBC, respectively. There was a greater response in the more acidic Andisol soil, with larger improvements in soil $\mathrm{pH}$, plant nutrient uptake and root biomass than the Oxisol. Surface application was as effective in increasing plant growth as the incorporated amendment, providing evidence for farm scale assessment. Biochar and compost are recommended for use in tropical soils, and surface application may be beneficial to annual and perennial crops.
\end{abstract}

Keywords Surface-applied · Andisol · Oxisol · Carica papaya $\cdot$ Brassica rapa chinensis $\cdot$ Biochar

\section{Introduction}

Many Hawaiian agricultural soils are constrained by low fertility and lack of nutrient retention due to weathering in the tropical climate. Andisols (developed from volcanic ash, pumice and cinder) typically have a high organic matter content, very high $\mathrm{P}$ sorption capacity and are low in $\mathrm{Ca}$, $\mathrm{Mg}$ and $\mathrm{K}$, creating a potentially $\mathrm{P}$ - and Ca-deficient soil, whereas Oxisols (developed from basaltic lava) are low in nutrients, and have high $\mathrm{Fe}$ and $\mathrm{Al}$ oxides, which reduce cation retention (Uehara and Ikawa 2000). Therefore, organic

Supplementary Information The online version contains supplementary material available at https://doi.org/10.1007/s4277 3-020-00081-z.

Justine Cox

coxja@hawaii.edu; justine.cox@dpi.nsw.gov.au

1 Tropical Plant and Soil Sciences, University of Hawaii, 3190 Maile Way, Honolulu, HI 96822, USA

2 Present Address: NSW Department Primary Industries, 1243 Bruxner Highway, Wollongbar, NSW 2477, Australia soil amendments play an important role in adding nutrients, improving nutrient retention, and reducing soil acidity in vegetable, fruit and nut production in Hawaii (Ahmad et al. 2016; Hue and Silva 2000), including commodities such as pineapples, coffee and macadamias.

Biochar, composts and manures have been identified as specific amendments to improve soil properties and crop production in Hawaii (Ahmad et al. 2014a; Berek and Hue 2016; Escobar and Hue 2008). The benefits of biochar application to soils have been shown to be due to increased moisture retention (Karhu et al. 2011; Sun and Lu 2014), increased nutrient retention (Berek et al. 2018; Glaser and Lehr 2019; Zheng et al. 2013), improved soil pH (Slavich et al. 2013; Van Zwieten et al. 2010, 2015), and improved soil microbial status (Lehmann et al. 2011; Palansooriya et al. 2019). However, biochar application is not universally successful in overcoming soil limitations, or increasing crop yields, with many examples of no effects (Jeffrey et al. 2011) perhaps due to the recalcitrant and low-nutrient properties of many biochars (Brassard et al. 2019).

Compost nutrients and labile organic matter are seen as complementary properties to the porous structure and high 
surface area of biochar and provide synergistic effect (Fischer and Glaser 2012; Liu et al. 2012). Attempts to examine this effect under different soil types, crops, biochar and compost types and climates often found the highest rate of biochar and compost combinations substantially increased crop yields and improved soil properties (Agegnehu et al. 2017; Di et al. 2019; Doan et al. 2015; Kammann et al. 2016; Manolikaki and Diamadopoulos 2019; Sadegh-Zadeh et al. 2018). Recent studies have ascertained that the combination is superior to the amendments on their own due to increased water-holding capacity, increased nutrient retention and nutrient use efficiency (especially $\mathrm{N}$ ), improved soil $\mathrm{pH}$ and CEC, decreased soil bulk density, increased soil macroaggregates, and suppressed disease (Agegnehu et al. 2015, 2016a, b; Akmal et al. 2019; Cao et al. 2018; Jien et al. 2018; Khorram et al. 2019; Liu et al. 2019; McDonald et al. 2019; Novak et al. 2019; Sánchez-Monedero et al. 2019). In Hawaii, several biochar and compost combinations significantly increased soil $\mathrm{pH}$, reduced $\mathrm{Al}, \mathrm{Mn}$ and $\mathrm{Fe}$ in the Oxisol, and for both the Oxisol and Ultisol, increased P, K and $\mathrm{Ca}$, overcoming many plant limitations to growth (Berek et al. 2018).

The benefits of biochar and compost applications are mostly described for amendments that have been incorporated into soil, enabling close contact between all the components. Unfortunately, in established perennial crops (e.g. trees), it is not possible to incorporate amendments due to substantial surface roots and established interrow groundcover species which would be damaged with incorporation (Oo et al. 2018; Paulin and O'Malley 2008). The option for these crops is limited to surface application, which relies on movement of soluble nutrients with rainfall/irrigation, then biological bioturbation and vertical transport of solutes/particles over time (Major et al. 2010). Application of biochar and compost to the soil surface of a banana plantation (Bass et al. 2016) and a macadamia orchard (Galanti et al. 2019) showed little difference in yield after 12 and 7 months, respectively, suggesting surface application may not be effective in this time frame, or that the amendments did not address a constraint of those soils.

Valid comparisons between surface and incorporated applications of biochar mixes are scant and require further investigation (Bass et al. 2016). Information on the fate of biochar and compost as surface-applied amendments is limited. There is evidence that surface wildfire char infiltrates the soil, where the dissolved fraction is mobile with rainfall over time, and particulate char rate of vertical movement from 3 to $30 \mathrm{~mm}$ per year has been measured (Rumpel et al. 2015). However, this contrasts with significant surface biochar losses due to erosion after field surface application, of $7-55 \%$ (Rumpel et al. 2009) and 20-53\% (Major et al. 2010). The risk is high for biochar lateral movement, especially down slope after rainfall events, due to the low density and porous structure of biochar (Rumpel et al. 2015; Wang et al. 2013). It is, therefore, suggested that a combination of biochar with compost could reduce this risk of lateral movement. Substantial vertical movement of incorporated biochar has also been shown, with $50 \%$ of biochar recovered below the incorporated zone in a sandy soil (Haefele et al. 2011) and 3.8-21.8\% recovered in a range of soil types (Singh et al. 2015). Singh et al. (2015) suggested that the movement of the fine particulate or the dissolved labile components of the biochar contributed to the recovered biochar carbon.

We hypothesised that the application of a combination of wood waste biochar and chicken manure compost would increase availability and plant uptake of nutrients in two soils constrained by low-nutrient holding capacity and poor fertility. We also aim to explain some of the processes involved in the effects of the combination amendment. To address these hypotheses, we compared incorporated and surface applications of a combination of wood waste biochar and chicken manure compost on the growth and nutrient uptake of an annual (Chinese cabbage) to represent typical incorporation and a perennial (papaya) for typical surface application methods.

\section{Materials and methods}

\subsection{Soil, biochar and compost characteristics}

The Oxisol (Very fine, kaolinitic, isohyperthermic rhodic haplustox, Wahiawa series) was sourced from central Oahu, and taken from the top $20 \mathrm{~cm}$ from the Poamoho Research Station of the University of Hawaii at Manoa. The Andisol (Medial over pumiceous or cindery, ferrihydritic, isothermic typic hapludand, Tantalus series) was sourced from the Lyon Arboretum of the University of Hawaii at Manoa. The two soils' properties are shown in Table 1. Soils were air dried and sieved through a 4-mm mesh, then $\mathrm{pH}$ and EC were measured using 1:5 water extract, total $\mathrm{C}$ and $\mathrm{N}$ using LECO combustion, available $\mathrm{P}$ and $\mathrm{K}$ using Mehlich 3 extraction, bulk density (BD) using mass of known volume and water-holding capacity (WHC) using moisture content of a gravity-drained saturated soil. Chicken manure compost from an aerated process using windrows was sourced from a commercial supplier (Niu Nursery). The compost had a $\mathrm{C}: \mathrm{N}$ ratio of 17.6 and further characteristics are shown in Table 1. The biochar was processed by the Landscape Ecology Corp from mixed hardwood pruning from Hilo, Hawaii, and heated to a maximum temperature of $450{ }^{\circ} \mathrm{C}$ for $2 \mathrm{~h}$ (properties shown in Table 1). The biochar total functional groups averaged $0.58 \mathrm{mmol} / \mathrm{g}$ with carboxylic, phenolic and lactonic groups at $0.22,0.27$ and $0.10 \mathrm{mmol} / \mathrm{g}$, with a cation exchange capacity (CEC) of 14.7 (Berek et al. 2018). 
Table 1 Soil and amendment properties at start of trial ( $\mathrm{pH}$ and EC determined on 1:5 extract, total $\mathrm{C}$ and $\mathrm{N}$ determined by LECO combustion, available $\mathrm{P}$ and $\mathrm{K}$ by Mehlich 3 extraction)

\begin{tabular}{lllllllll}
\hline & $\mathrm{pH}($ water$)$ & $\mathrm{EC}(\mathrm{dS} / \mathrm{m})$ & $\mathrm{C}(\%)$ & $\mathrm{N}(\%)$ & $\mathrm{P}(\mathrm{mg} / \mathrm{kg})$ & $\mathrm{K}(\mathrm{mg} / \mathrm{kg})$ & $\mathrm{BD}\left(\mathrm{g} / \mathrm{cm}^{3}\right)$ & $\mathrm{WHC}(\%)$ \\
\hline Biochar & 8.4 & 1.63 & 49.81 & 0.46 & 978 & 3954 & 0.52 & - \\
Compost & 7.0 & 3.23 & 29.37 & 1.67 & 6801 & 5440 & 0.87 & - \\
Andisol & 6.0 & 0.15 & 2.52 & 0.17 & 5.3 & 137 & 0.74 & 32 \\
Oxisol & 6.9 & 0.30 & 1.45 & 0.14 & 147.2 & 447 & 0.92 & 35 \\
\hline
\end{tabular}

Compost and biochar were air dried and sieved through a 4-mm mesh.

The applied amendment was a 1:1 compost:biochar blend by volume on a dry matter basis and combined at the trial establishment. The dry rate of biochar and compost application was calculated as $4 \%$ by volume each, and were combined together just prior to the application to the soil (all treatments were calculated to fill 1.531 per pot). Therefore, $16.9 \mathrm{~g}$ of biochar and $28.3 \mathrm{~g}$ compost (dry weight) were used per pot. In the Andisol, there was $1.4 \mathrm{~kg}$ soil $/$ pot and $1.6 \mathrm{~kg} /$ pot in the Oxisol. The rates of biochar and compost were the equivalent in the Andisol of $14.8 \mathrm{t} / \mathrm{ha}$ and $26.0 \mathrm{t} / \mathrm{ha}$ (dry weight) and $18.4 \mathrm{t} / \mathrm{ha}$ and $32 \mathrm{t} / \mathrm{ha}$ in the Oxisol.

\subsection{Experimental site and design}

The glasshouse trial was conducted at Magoon's greenhouse facility of the University of Hawaii at Manoa (37 25.82' N, $\left.12205.36^{\prime} \mathrm{W}\right)$. Tree pots $(10 \times 10 \times 34 \mathrm{~cm}$ tapered, $2.65 \mathrm{l})$ were used to conduct the pot trials. The experimental design consisted of two soils (Oxisol and Andisol) with two amendment placements (surface, incorporated) compared to controls (unamended) with four replicates. Treatments were established, and each replicate pot was placed randomly on benches (blocks) in a randomised complete block design (RCBD).

\subsection{Pot trial 1, Nov 2017}

The mineral fertilisers required for the two soil types were calculated from both the initial soil analysis and the requirements to grow Chinese cabbage, Brassica rapa chinensis group, cv. (Mei Qing). The plant required $200 \mathrm{mg} / \mathrm{kg}$ soil of $\mathrm{N}$, which was applied as urea $(711 \mathrm{mg}$ urea/pot, and therefore, $320 \mathrm{mg} \mathrm{N} / \mathrm{pot}$ ) for the Oxisol and NPK 16-16-16 $(1.75 \mathrm{~g} / \mathrm{pot}$, and therefore, $280 \mathrm{mg} \mathrm{N} / \mathrm{pot}$ ) for the Andisol. This was sufficient NPK for crop growth for both soils. The 10-20 cm layers were prepared separately from the $0-10 \mathrm{~cm}$ soil layers. Mineral fertiliser was mixed with each soil and placed into the $10-20 \mathrm{~cm}$ layer of each pot at lab determined bulk density. For the $0-10 \mathrm{~cm}$ layer, the control and surface treatments were the same, with soils mixed with mineral fertiliser. For the surface treatment (SBC), the compost and biochar amendments were mixed and then immediately placed on the soil surface. For the incorporated treatment (IBC), the mixed amendments were thoroughly mixed with the soil (0-10 $\mathrm{cm}$ layer), and placed above the 10-20 cm layer. The biochar contributed $78 \mathrm{mg} \mathrm{N}, 17 \mathrm{mg}$ $\mathrm{P}$ and $67 \mathrm{mg} \mathrm{K}$ (total) per pot, and the compost contributed $473 \mathrm{mg} \mathrm{N}, 192 \mathrm{mg} \mathrm{P}$ and $154 \mathrm{mg} \mathrm{K}$ (total) per pot. The pots were watered and left to equilibrate for 3 days.

The pots were planted on 28 November 2017 with Chinese cabbage seedlings or with papaya (Carica papaya cv Sunrise) seedlings $(n=4)$ making a total of 48 pots ( 1 plant/pot). Seedlings were started 3 weeks prior to transplanting using 50 cells trays and Sunshine peatmoss. Pots were hand watered every other day for the first 4 weeks, and then watered daily to the end of the trial, according to a regime for each soil type and crop. Water was provided to achieve field capacity and limit plant wilting; therefore, some water leaching was observed. By harvest, Chinese cabbage had $3350 \mathrm{ml} /$ pot of water for Andisol and $3650 \mathrm{ml} /$ pot for Oxisol applied. Papaya plants had $6150 \mathrm{ml} /$ pot of water for Andisol and $6790 \mathrm{ml} /$ pot for Oxisol applied. Plant above ground biomass was harvested after 8 weeks for Chinese cabbage and 14 weeks for papaya, dried at $70{ }^{\circ} \mathrm{C}$ till it reached constant weight and weighed. The surface amendment remaining on top of the SBC treatments that was loose was carefully removed and discarded, where the amendment was not embedded and part of the soil profile. This meant that the IBC and SBC would not be comparable in terms of absolute $\mathrm{C}$ contribution from the amendments. The pot was cut horizontally with a knife at the $10 \mathrm{~cm}$ line to split the $0-10$ and $10-20 \mathrm{~cm}$ layers. Roots from both layers were separated from the soil, placed in bags and refrigerated until assessment. Soil was collected, air dried and sieved to pass a 2-mm mesh.

\subsection{Pot trial 2, May 2018}

The second pot trial was a replication of the 1st trial using Chinese cabbage crop only, and the two soil types, with identical methodology. The repeat experiment was performed only on the short-term crop, in a different season to examine this influence. Three-week-old Chinese cabbage seedlings were transplanted on 1 May 2018, 3 days after 
initial watering and equilibrating. Plants were watered every other day for the first 2 weeks and then daily. By harvest, $6030 \mathrm{ml} /$ pot of water for Andisol and $6390 \mathrm{ml} /$ pot for Oxisol had been applied. Plants were harvested after 5 weeks as growth was faster in the warmer season, and soil and root samples were collected from each layer for each pot, as described in the first pot trial.

\subsection{Soil analyses}

Total $\mathrm{C}$ and $\mathrm{N}$ were determined by combustion using a LECO C-N analyser (TruSpec CN). Soil available nutrients $\mathrm{P}, \mathrm{Na}, \mathrm{Mg}, \mathrm{K}$, and $\mathrm{Ca}$ were determined by Mehlich 3 extraction $(2.0 \mathrm{~g}$ in $20 \mathrm{ml})$ as described by Mehlich (1984) and measured using an ICP spectrometer (PerkinElmer Optima series). Soil $\mathrm{pH}$ and EC were measured in a 1:1 mixture of soil and deionised water $(20 \mathrm{~g}$ and $20 \mathrm{ml})$, after shaking for an hour using a HANNA pH/EC combo meter. Soil nitrate $\left(\mathrm{NO}_{3}-\mathrm{N}\right)$ and ammonium $\left(\mathrm{NH}_{4}-\mathrm{N}\right)$ concentrations were also measured on 1:1 soil and water mixture, after shaking for an hour, using Vernier ion-selective electrodes. At each time of measurement, the electrodes were calibrated using calibration solution and a calibration curve was established using set of solutions with known $\mathrm{NO}_{3}$ and $\mathrm{NH}_{4}$ concentrations.

\subsection{Plant harvest and nutrient analyses}

At harvest, the above ground biomass was dried to $70{ }^{\circ} \mathrm{C}$ for $72 \mathrm{~h}$ or until a constant weight was reached. Each plant biomass was finely ground, ashed at $500{ }^{\circ} \mathrm{C}$ for $4 \mathrm{~h}$, then dissolved in $0.01 \mathrm{M} \mathrm{HCl}$ solution $(0.25 \mathrm{~g}$ in $20 \mathrm{ml})$. The extract solution was analysed for $\mathrm{P}, \mathrm{Na}, \mathrm{Mg}, \mathrm{K}$, and Ca using an ICP. Total $\mathrm{N}$ was determined using the LECO analyzer. Total nutrient uptake per plant was calculated by multiplying concentration with dry biomass weight. Roots were shaken to remove most soil from both the $0-10$ and $10-20 \mathrm{~cm}$ layers. Each root mass was air dried on paper, then the remaining attached dried soil was separated from the roots and just the roots visually ranked for biomass on a scale of 1-5 (small to large) for each soil and crop type as described by Walters and Wehner (1994).

\subsection{Statistics}

A two-way factorial analysis of variance (ANOVA) was conducted, using the STATISTIX V10, for each crop to compare the effects of amendment and soil type on each parameter. Tukey's mean separation was used at $5 \%$ probability for the significant parameters.

\section{Results}

\subsection{Chinese cabbage}

\subsubsection{Soil}

Both surface-applied (SBC) and incorporated (IBC) amendments significantly increased soil $\mathrm{pH}$, total $\mathrm{C}, \mathrm{P}$, $\mathrm{Ca}$, and $\mathrm{Mg}$ in the $0-10 \mathrm{~cm}$ soil layer at harvest, when both soil types were combined. In the $10-20 \mathrm{~cm}$ layer, both amendments only significantly increased $\mathrm{Mg}$ concentration. In addition, only IBC significantly increased total $\mathrm{N}$ and $\mathrm{NO}_{3}-\mathrm{N}$ concentrations in the $0-10 \mathrm{~cm}$ soil layer, and total $\mathrm{C}, \mathrm{pH}, \mathrm{Ca}$ in the $10-20 \mathrm{~cm}$ layer. The IBC also significantly reduced $\mathrm{K}$ concentration at $10-20 \mathrm{~cm}$. Only SBC significantly increased $\mathrm{K}$ concentration in the $0-10 \mathrm{~cm}$ layer and $\mathrm{P}$ concentration in the $10-20 \mathrm{~cm}$ layer. In some cases, there were interactions with soil type, with the Andisol responding differently than the Oxisol.

In the Andisol, $\mathrm{pH}$ was significantly increased with both IBC and SBC in the $0-10 \mathrm{~cm}$ layer, but only IBC in the Oxisol. At harvest in trial 1, the Andisol's pH increased by 0.31 units for SBC and 0.77 units for IBC (Table 2). In the Oxisol, pH significantly increased by 0.39 units for IBC. Even though there were no amendments in the $10-20 \mathrm{~cm}$ layer, soil $\mathrm{pH}$ was significantly higher in this layer for the IBC amended Andisol soil. In trial 2, both IBC and SBC significantly increased $\mathrm{pH}$ in the $10-20 \mathrm{~cm}$ layer (Table 3 ).

Soil EC in trial 1 was not different to the unamended soil in the $0-10 \mathrm{~cm}$ layer (Table 2). In the $10-20 \mathrm{~cm}$ layer with the IBC and SBC, soil EC were $88 \%$ and $50 \%$ significantly higher than that in the unamended in the Oxisol, respectively. Just in the IBC, soil EC was significantly higher (2.3 times) than that in the unamended Andisol. In trial 2, soil EC was significantly higher in the IBC soils (64\%) than that in the unamended for the $0-10 \mathrm{~cm}$ layer in the Andisol (Table 3).

Soil C was $47 \%$ significantly higher with the IBC amendment than that in the unamended Andisol soil in the 0-10 cm layer for trial 1 (Table 2). The Oxisol C content in the IBC was $87 \%$ significantly higher than that in the unamended Oxisol soil. The total $C$ value of the SBC was not a comparable measure, however, due to the sampling process of removing the remaining surface amendment before soil analyses. In trial 2, however, SBC did significantly increase soil $\mathrm{C}$ content in the $0-10 \mathrm{~cm}$ layer for both soil types (Table 3 ). Total soil $\mathrm{C}$ had significantly increased in the 10-20 cm layer in the Andisol (22\%) compared to the unamended, despite no amendment present initially, which was also seen in trial 1 .

Total $\mathrm{N}$ was only significantly higher in the IBC than that in the unamended soil in the $0-10 \mathrm{~cm}$ layer of the 
Table 2 Soil chemical properties at harvest of Chinese cabbage (trial 1 established in November 2017) for both $0-10 \mathrm{~cm}$ and $10-20 \mathrm{~cm}$ layers for the two soil types $(n=4)$ and significance of treatment effect (different letters signify a statistical difference at $p<0.05$ along each row)
Table 3 Soil chemical properties at harvest of Chinese cabbage (trial 2 established in May 2018) for the two soil types $(n=4)$ and significance of treatment effect (different letters signify a statistical difference at $p<0.05$ along each row)

\begin{tabular}{|c|c|c|c|c|c|c|}
\hline & \multicolumn{3}{|l|}{ Andisol } & \multicolumn{3}{|l|}{ Oxisol } \\
\hline & Control & Incorp & Surface & Control & Incorp & Surface \\
\hline \multicolumn{7}{|l|}{$0-10 \mathrm{~cm}$} \\
\hline $\mathrm{pH}$ (water) & $5.57^{\mathrm{e}}$ & $6.34^{\mathrm{c}}$ & $5.89^{\mathrm{d}}$ & $6.84^{\mathrm{b}}$ & $7.23^{\mathrm{a}}$ & $7.01^{\mathrm{ab}}$ \\
\hline $\mathrm{EC}(\mathrm{dS} / \mathrm{m})$ & $0.25^{\mathrm{b}}$ & $0.35^{\mathrm{ab}}$ & $0.26^{\mathrm{ab}}$ & $0.45^{\mathrm{ab}}$ & $0.46^{\mathrm{a}}$ & $0.41^{\mathrm{ab}}$ \\
\hline $\mathrm{NO}_{3}-\mathrm{N}(\mathrm{mg} / \mathrm{kg})$ & $1.05^{\mathrm{c}}$ & $9.18^{c}$ & $2.55^{\mathrm{c}}$ & $18.1^{\mathrm{b}}$ & $36.5^{\mathrm{a}}$ & $23.8^{\mathrm{b}}$ \\
\hline $\mathrm{NH}_{4}-\mathrm{N}(\mathrm{mg} / \mathrm{kg})$ & $0.23^{\mathrm{ab}}$ & $0.13^{\mathrm{b}}$ & $0.30^{\mathrm{ab}}$ & $0.30^{\mathrm{ab}}$ & $0.33^{\mathrm{ab}}$ & $0.40^{\mathrm{a}}$ \\
\hline Total C (\%) & $2.16^{\mathrm{bc}}$ & $3.18^{\mathrm{a}}$ & $2.48^{\mathrm{ab}}$ & $1.33^{\mathrm{c}}$ & $2.50^{\mathrm{ab}}$ & $2.05^{\mathrm{bc}}$ \\
\hline Total N (\%) & $0.16^{\mathrm{b}}$ & $0.19^{\mathrm{a}}$ & $0.17^{\mathrm{ab}}$ & $0.15^{\mathrm{b}}$ & $0.18^{\mathrm{ab}}$ & $0.17^{\mathrm{ab}}$ \\
\hline $\mathrm{P}(\mathrm{mg} / \mathrm{kg})$ & $16.3^{\mathrm{d}}$ & $24.6^{\mathrm{d}}$ & $22.7^{\mathrm{d}}$ & $94.5^{\mathrm{c}}$ & $150.9^{\mathrm{b}}$ & $184.8^{\mathrm{a}}$ \\
\hline $\mathrm{K}(\mathrm{mg} / \mathrm{kg})$ & $71^{\mathrm{d}}$ & $120^{\mathrm{d}}$ & $116^{\mathrm{d}}$ & $604^{b}$ & $481^{\mathrm{c}}$ & $764^{\mathrm{a}}$ \\
\hline $\mathrm{Ca}(\mathrm{mg} / \mathrm{kg})$ & $1227^{\mathrm{d}}$ & $3313^{b}$ & $1836^{\mathrm{c}}$ & $2115^{\mathrm{c}}$ & $3763^{\mathrm{a}}$ & $3884^{\mathrm{a}}$ \\
\hline $\mathrm{Mg}(\mathrm{mg} / \mathrm{kg})$ & $654^{\mathrm{cd}}$ & $750^{\mathrm{ab}}$ & $705^{\mathrm{bc}}$ & $548^{\mathrm{e}}$ & $626^{\mathrm{d}}$ & $787^{\mathrm{a}}$ \\
\hline \multicolumn{7}{|l|}{$10-20 \mathrm{~cm}$} \\
\hline pH (water) & $5.41^{\mathrm{c}}$ & $5.79^{\mathrm{b}}$ & $5.55^{\mathrm{bc}}$ & $6.52^{\mathrm{a}}$ & $6.57^{\mathrm{a}}$ & $6.45^{\mathrm{a}}$ \\
\hline $\mathrm{EC}(\mathrm{dS} / \mathrm{m})$ & $0.27^{\mathrm{d}}$ & $0.62^{\mathrm{b}}$ & $0.38^{\mathrm{cd}}$ & $0.42^{\mathrm{c}}$ & $0.79^{\mathrm{a}}$ & $0.63^{\mathrm{b}}$ \\
\hline $\mathrm{NO}_{3}-\mathrm{N}(\mathrm{mg} / \mathrm{kg})$ & $1.10^{\mathrm{b}}$ & $2.15^{\mathrm{b}}$ & $3.79^{\mathrm{b}}$ & $22.9^{\mathrm{ab}}$ & $43.8^{\mathrm{a}}$ & $30.4^{\mathrm{ab}}$ \\
\hline $\mathrm{NH}_{4}-\mathrm{N}(\mathrm{mg} / \mathrm{kg})$ & $3.11^{\mathrm{ab}}$ & $0.18^{\mathrm{b}}$ & $7.04^{\mathrm{a}}$ & $0.23^{\mathrm{b}}$ & $0.20^{\mathrm{b}}$ & $0.27^{\mathrm{b}}$ \\
\hline Total C (\%) & $2.09^{\mathrm{b}}$ & $2.56^{\mathrm{a}}$ & $1.97^{\mathrm{b}}$ & $1.32^{\mathrm{c}}$ & $1.39^{c}$ & $1.41^{\mathrm{c}}$ \\
\hline Total N (\%) & $0.16^{\mathrm{ab}}$ & $0.18^{\mathrm{a}}$ & $0.16^{\mathrm{ab}}$ & $0.15^{\mathrm{b}}$ & $0.15^{\mathrm{b}}$ & $0.16^{\mathrm{b}}$ \\
\hline $\mathrm{P}(\mathrm{mg} / \mathrm{kg})$ & $16.0^{\mathrm{c}}$ & $18.4^{\mathrm{c}}$ & $17.6^{\mathrm{c}}$ & $93.9^{\mathrm{b}}$ & $99.7^{\mathrm{b}}$ & $128.5^{\mathrm{a}}$ \\
\hline $\mathrm{K}(\mathrm{mg} / \mathrm{kg})$ & $117^{b c}$ & $58^{c}$ & $176^{\mathrm{b}}$ & $321^{\mathrm{a}}$ & $191^{\mathrm{b}}$ & $332^{\mathrm{a}}$ \\
\hline $\mathrm{Ca}(\mathrm{mg} / \mathrm{kg})$ & $1195^{c}$ & $2149^{b}$ & $1299^{c}$ & $2213^{\mathrm{ab}}$ & $2853^{\mathrm{ab}}$ & $2915^{\mathrm{a}}$ \\
\hline $\mathrm{Mg}(\mathrm{mg} / \mathrm{kg})$ & $632^{\mathrm{bc}}$ & $739^{a}$ & $703^{\mathrm{ab}}$ & $520^{\mathrm{d}}$ & $543^{\text {cd }}$ & $719^{\mathrm{ab}}$ \\
\hline
\end{tabular}

\begin{tabular}{|c|c|c|c|c|c|c|}
\hline & \multicolumn{3}{|l|}{ Andisol } & \multicolumn{3}{|l|}{ Oxisol } \\
\hline & Control & Incorp & Surface & Control & Incorp & Surface \\
\hline \multicolumn{7}{|l|}{$0-10 \mathrm{~cm}$} \\
\hline $\mathrm{pH}$ (water) & $5.32^{\mathrm{d}}$ & $5.89^{c}$ & $5.73^{c}$ & $6.33^{\mathrm{b}}$ & $6.73^{\mathrm{a}}$ & $6.64^{\mathrm{a}}$ \\
\hline $\mathrm{EC}(\mathrm{dS} / \mathrm{m})$ & $0.14^{\mathrm{c}}$ & $0.23^{\mathrm{b}}$ & $0.17^{\mathrm{c}}$ & $0.29^{\mathrm{a}}$ & $0.28^{\mathrm{ab}}$ & $0.29^{\mathrm{ab}}$ \\
\hline $\mathrm{NO}_{3}-\mathrm{N}(\mathrm{mg} / \mathrm{kg})$ & $4.57^{\mathrm{b}}$ & $6.64^{\mathrm{ab}}$ & $6.54^{\mathrm{ab}}$ & $4.50^{\mathrm{b}}$ & $8.67^{\mathrm{a}}$ & $8.15^{\mathrm{a}}$ \\
\hline $\mathrm{NH}_{4}-\mathrm{N}(\mathrm{mg} / \mathrm{kg})$ & $0.1^{\mathrm{c}}$ & $0.1^{\mathrm{c}}$ & $0.1^{\mathrm{c}}$ & $0.33^{\mathrm{a}}$ & $0.25^{\mathrm{b}}$ & $0.2^{\mathrm{b}}$ \\
\hline Total C (\%) & $1.56^{\mathrm{c}}$ & $3.04^{\mathrm{a}}$ & $1.96^{\mathrm{b}}$ & $1.30^{\mathrm{c}}$ & $2.90^{\mathrm{a}}$ & $2.18^{\mathrm{b}}$ \\
\hline Total N (\%) & $0.10^{\mathrm{bc}}$ & $0.11^{\mathrm{bc}}$ & $0.08^{\mathrm{c}}$ & $0.09^{c}$ & $0.13^{\mathrm{b}}$ & $0.17^{\mathrm{a}}$ \\
\hline $\mathrm{P}(\mathrm{mg} / \mathrm{kg})$ & $4.03^{c}$ & $5.20^{\mathrm{c}}$ & $3.47^{\mathrm{c}}$ & $101^{\mathrm{b}}$ & $107^{\mathrm{a}}$ & $101^{\mathrm{b}}$ \\
\hline $\mathrm{K}(\mathrm{mg} / \mathrm{kg})$ & $102^{\mathrm{c}}$ & $57^{\mathrm{c}}$ & $115^{\mathrm{c}}$ & $504^{\mathrm{a}}$ & $361^{\mathrm{b}}$ & $392^{\mathrm{b}}$ \\
\hline $\mathrm{Ca}(\mathrm{mg} / \mathrm{kg})$ & $608^{\mathrm{d}}$ & $1939^{b}$ & $1163^{\mathrm{c}}$ & $1726^{\mathrm{b}}$ & $2552^{\mathrm{a}}$ & $2312^{\mathrm{a}}$ \\
\hline $\mathrm{Mg}(\mathrm{mg} / \mathrm{kg})$ & $611^{\mathrm{b}}$ & $723^{\mathrm{a}}$ & $654^{\mathrm{b}}$ & $424^{\mathrm{d}}$ & $532^{\mathrm{c}}$ & $512^{\mathrm{c}}$ \\
\hline \multicolumn{7}{|l|}{$10-20 \mathrm{~cm}$} \\
\hline $\mathrm{pH}$ (water) & $5.32^{\mathrm{e}}$ & $5.55^{\mathrm{d}}$ & $5.52^{\mathrm{d}}$ & $6.15^{\mathrm{c}}$ & $6.62^{\mathrm{a}}$ & $6.41^{\mathrm{b}}$ \\
\hline $\mathrm{EC}(\mathrm{dS} / \mathrm{m})$ & 0.24 & 0.30 & 0.29 & 0.30 & 0.26 & 0.23 \\
\hline $\mathrm{NO}_{3}-\mathrm{N}(\mathrm{mg} / \mathrm{kg})$ & 15.21 & 6.23 & 19.33 & 4.26 & 4.46 & 3.06 \\
\hline $\mathrm{NH}_{4}-\mathrm{N}(\mathrm{mg} / \mathrm{kg})$ & $2.38^{\mathrm{a}}$ & $0.1^{\mathrm{b}}$ & $0.58^{\mathrm{ab}}$ & $0.4^{\mathrm{b}}$ & $0.1^{\mathrm{b}}$ & $0.1^{\mathrm{b}}$ \\
\hline Total C (\%) & $1.54^{\mathrm{abc}}$ & $1.73^{\mathrm{a}}$ & $1.57^{\mathrm{ab}}$ & $1.29^{\mathrm{d}}$ & $1.45^{\mathrm{bcd}}$ & $1.31^{\mathrm{cd}}$ \\
\hline Total N (\%) & $0.11^{\mathrm{bc}}$ & $0.08^{\mathrm{cd}}$ & $0.07^{\mathrm{d}}$ & $0.10^{\mathrm{bcd}}$ & $0.13^{\mathrm{ab}}$ & $0.16^{\mathrm{a}}$ \\
\hline $\mathrm{P}(\mathrm{mg} / \mathrm{kg})$ & $4.34 b$ & $4.05^{\mathrm{b}}$ & $4.30^{\mathrm{b}}$ & $103^{\mathrm{a}}$ & $99^{a}$ & $96^{\mathrm{a}}$ \\
\hline $\mathrm{K}(\mathrm{mg} / \mathrm{kg})$ & $229^{b}$ & $45^{\mathrm{c}}$ & $145^{\mathrm{bc}}$ & $491^{\mathrm{a}}$ & $242^{\mathrm{b}}$ & $225^{\mathrm{b}}$ \\
\hline $\mathrm{Ca}(\mathrm{mg} / \mathrm{kg})$ & 635 & $1057^{b}$ & $931^{\mathrm{b}}$ & $1753^{\mathrm{a}}$ & $1875^{\mathrm{a}}$ & $1788^{\mathrm{a}}$ \\
\hline $\mathrm{Mg}(\mathrm{mg} / \mathrm{kg})$ & $639^{a}$ & $644^{\mathrm{a}}$ & $681^{\mathrm{a}}$ & $376^{\mathrm{b}}$ & $400^{\mathrm{b}}$ & $384^{\mathrm{b}}$ \\
\hline
\end{tabular}


Andisol for trial 1, but both IBC and SBC significantly increased $\mathrm{N}$ in the Oxisol compared to the unamended soil in trial 2 (Tables 2 and 3). Nitrate $\mathrm{N}$ was only significantly higher in the IBC (50\%) than that in the unamended in the $0-10 \mathrm{~cm}$ layer of the Oxisol for trial 1, but both IBC and SBC $(48 \%, 45 \%)$ significantly increased Nitrate $\mathrm{N}$ than the unamended in trial 2.

Both IBC and SBC amendments significantly increased soil nutrients $\mathrm{P}, \mathrm{Ca}, \mathrm{Mg}$ in the $0-10 \mathrm{~cm}$ layer of the Oxisol, whereas in the Andisol only $\mathrm{Ca}$ was significantly higher than that in the unamended soil in trial 1 (Table 2). In the Oxisol, $\mathrm{K}$ significantly reduced in the IBC but significantly increased in the SBC compared to the unamended soil. Soil $\mathrm{P}$ was $96 \%$ significantly higher in the SBC and $60 \%$ significantly higher in the IBC than that in the unamended Oxisol soil in the $0-10 \mathrm{~cm}$ layer, and even $37 \%$ significantly higher in the SBC than that in the unamended in the $10-20 \mathrm{~cm}$ layer in trial 1. In trial 2, for soil nutrients $\mathrm{P}, \mathrm{Mg}$ in the $0-10 \mathrm{~cm}$ layer of two soil types, only IBC was significantly higher than the unamended. Soil Ca was significantly higher in both IBC and SBC than that in the unamended.

\subsubsection{Chinese cabbage biomass}

Combining both soil types and dates, dry weight plant biomass was significantly higher in both IBC and SBC, than that in the unamended soil. The response in trial 1 to the amendments was smaller than the response in trial 2 despite the shorter growth period (Fig. 1). In trial 1, SBC produced $23 \%$ significantly larger plants than the unamended in the Andisol, yet there was no difference in the Oxisol. However, in trial 2, both SBC (54\%) and IBC (54\%) had significantly

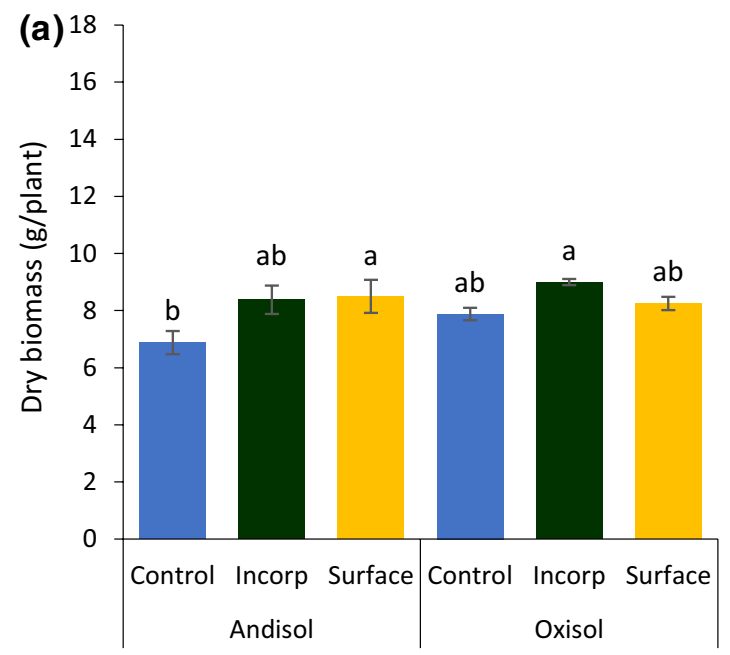

Fig. 1 Chinese cabbage dry weight biomass (g/plant) in Andisol and Oxisol soils for control, incorporated and surface-applied treatments for a trial 1 (November 2017) and b trial 2 (May 2018), with standard higher biomass than the unamended in the Oxisol. The IBC had $92 \%$ significantly higher biomass than the unamended in the Andisol.

The soil amendments had only a small impact on the plant nutrient concentration at harvest (Supplementary material 1). Total $\mathrm{N}$ in the plants was significantly lower in the IBC than that in the unamended Andisol, in trial 1. In the Andisol soil, plant $\mathrm{Ca}$ was significantly higher in the IBC than that in the unamended in trial 1 and plant $\mathrm{K}$ was significantly higher in the SBC than that in the unamended in trial 2. In the Oxisol, there were no other differences for plant $\mathrm{K}, \mathrm{P}$ and $\mathrm{Mg}$.

Calculated total plant nutrient uptake, however, was significantly higher in the $\mathrm{SBC}$ for $\mathrm{N}, \mathrm{K}, \mathrm{Ca}, \mathrm{Mg}$, plus also in the IBC for $\mathrm{Ca}$ in trial 1 (Table 4) given the influence of plant size. In trial 2, plant uptake of $\mathrm{N}, \mathrm{P}, \mathrm{K}$ and $\mathrm{Ca}$ were all significantly higher in both IBC and SBC.

\subsubsection{Chinese cabbage roots}

The majority of the roots were in the $10-20 \mathrm{~cm}$ layer for the Oxisol and the Andisol had roots distributed through both layers. Overall, in the $0-10 \mathrm{~cm}$ layer, both SBC and IBC resulted in higher root biomass than the unamended (up to double) for both trial dates (Fig. 2). In the 10-20 cm soil layer, however, only the IBC resulted in significantly higher root biomass than the unamended for trial 1, but both IBC and SBC significantly increased root biomass in trial 2. The roots had a significantly greater biomass in the $0-10 \mathrm{~cm}$ layer in the Andisol compared to the Oxisol, but this was reversed for the $10-20 \mathrm{~cm}$ soil layer.

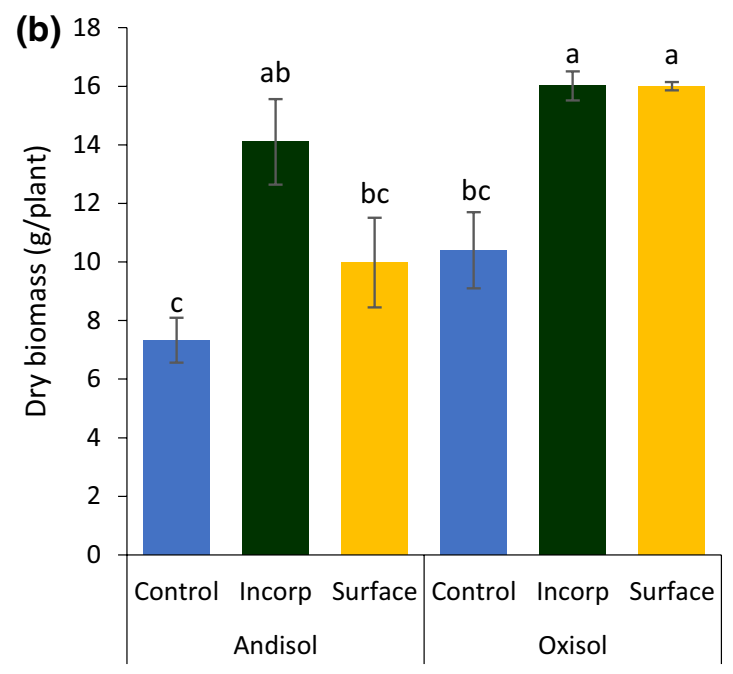

error $(n=4)$, and significance of treatment effect (different letters signify a statistical difference at $p<0.05$ ) 
Table 4 Total nutrient uptake (mg/plant) at harvest of Chinese cabbage for trials established in November 2017 and May 2018, for the two soil types $(n=4)$ and significance of treatment effect (different letters signify a statistical difference at $p<0.05$ along each row)

Fig. 2 Root biomass rank of Chinese cabbage in Andisol and Oxisol soils for control, incorporated and surfaceapplied treatments for a trial 1 (November 2017) and b trial 2 (May 2018), with standard error $(n=4)$ and significance of treatment effect (different letters signify a statistical difference at $p<0.05$ with lowercase letters comparing the $0-10 \mathrm{~cm}$ layer and uppercase letters comparing the $10-20 \mathrm{~cm}$ layer). Each plant's root biomass was visually ranked from 1 to 5 , low to high, after drying and soil removed (Walters and Wehner 1994)

\begin{tabular}{|c|c|c|c|c|c|c|}
\hline & \multicolumn{3}{|l|}{ Andisol } & \multicolumn{3}{|l|}{ Oxisol } \\
\hline & Control & Incorp & Surface & Control & Incorp & Surface \\
\hline \multicolumn{7}{|c|}{ Trial 1} \\
\hline $\mathrm{N}$ & $267^{\mathrm{de}}$ & $219^{\mathrm{e}}$ & $297^{\mathrm{cd}}$ & $343^{b c}$ & $406^{\mathrm{a}}$ & $397^{\mathrm{ab}}$ \\
\hline K & $394^{\mathrm{b}}$ & $422^{\mathrm{b}}$ & $505^{\mathrm{b}}$ & $747^{\mathrm{a}}$ & $817^{\mathrm{a}}$ & $806^{\mathrm{a}}$ \\
\hline $\mathrm{P}$ & $23^{\mathrm{b}}$ & $37^{\mathrm{a}}$ & $34^{\mathrm{ab}}$ & $38^{\mathrm{a}}$ & $39^{\mathrm{a}}$ & $39^{\mathrm{a}}$ \\
\hline $\mathrm{Ca}$ & $86^{\mathrm{d}}$ & $183^{\mathrm{a}}$ & $123^{c}$ & $141^{\mathrm{bc}}$ & $189^{\mathrm{a}}$ & $172^{\mathrm{ab}}$ \\
\hline $\mathrm{Mg}$ & $54^{\mathrm{ab}}$ & $56^{\mathrm{a}}$ & $60^{\mathrm{a}}$ & $40^{\mathrm{c}}$ & $43^{c}$ & $46^{\mathrm{bc}}$ \\
\hline \multicolumn{7}{|c|}{ Trial 2} \\
\hline $\mathrm{N}$ & $177^{\mathrm{c}}$ & $254^{\mathrm{abc}}$ & $241^{a b c}$ & $230^{\mathrm{bc}}$ & $305^{\mathrm{ab}}$ & $310^{\mathrm{a}}$ \\
\hline K & $242^{\mathrm{d}}$ & $615^{\mathrm{b}}$ & $499^{b c}$ & $383^{\mathrm{cd}}$ & $880^{\mathrm{a}}$ & $873^{\mathrm{a}}$ \\
\hline $\mathrm{P}$ & $22^{c}$ & $45^{\mathrm{b}}$ & $39^{\mathrm{bc}}$ & $51^{\mathrm{b}}$ & $80^{\mathrm{a}}$ & $87^{\mathrm{a}}$ \\
\hline $\mathrm{Ca}$ & $105^{\mathrm{c}}$ & $197^{\mathrm{b}}$ & $171^{\mathrm{bc}}$ & $208^{b}$ & $288^{\mathrm{a}}$ & $290^{\mathrm{a}}$ \\
\hline $\mathrm{Mg}$ & $98^{\mathrm{a}}$ & $91^{\mathrm{ab}}$ & $94^{\mathrm{a}}$ & $38^{\mathrm{c}}$ & $55^{\mathrm{bc}}$ & $56^{\mathrm{bc}}$ \\
\hline
\end{tabular}
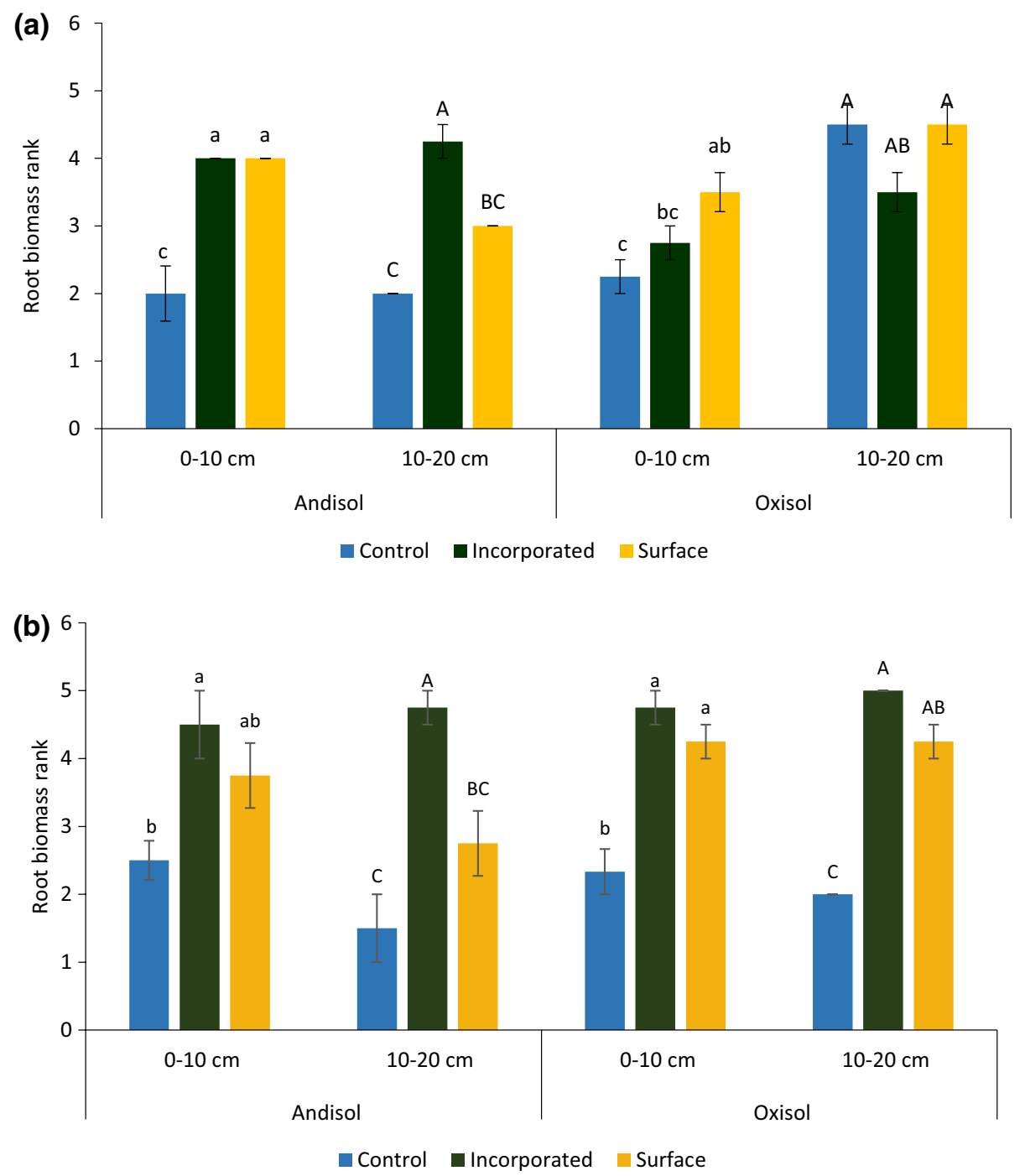
Table 5 Soil chemical properties at harvest of papaya (established May 2018) for the two soil types $(n=4)$ and significance of treatment effect (different letters signify a statistical difference at $p<0.05$ along each row)

\begin{tabular}{|c|c|c|c|c|c|c|}
\hline & \multicolumn{3}{|l|}{ Andisol } & \multicolumn{3}{|l|}{ Oxisol } \\
\hline & Control & Incorp & Surface & Control & Incorp & Surface \\
\hline \multicolumn{7}{|l|}{$0-10 \mathrm{~cm}$} \\
\hline $\mathrm{pH}$ (water) & $5.38^{\mathrm{d}}$ & $6.43^{\mathrm{b}}$ & $5.84^{\mathrm{c}}$ & $6.44^{\mathrm{b}}$ & $6.89^{\mathrm{a}}$ & $6.88^{\mathrm{a}}$ \\
\hline $\mathrm{EC}(\mathrm{dS} / \mathrm{m})$ & $0.38^{\mathrm{b}}$ & $0.52^{\mathrm{ab}}$ & $0.48^{\mathrm{ab}}$ & $0.45^{\mathrm{ab}}$ & $0.61^{\mathrm{a}}$ & $0.63^{\mathrm{a}}$ \\
\hline $\mathrm{NO}_{3}-\mathrm{N}(\mathrm{mg} / \mathrm{kg})$ & $1.5^{\mathrm{b}}$ & $9.3^{\mathrm{ab}}$ & $4.8^{\mathrm{ab}}$ & $13.3^{\mathrm{ab}}$ & $20.2^{\mathrm{a}}$ & $11.9^{\mathrm{ab}}$ \\
\hline $\mathrm{NH}_{4}-\mathrm{N}(\mathrm{mg} / \mathrm{kg})$ & $0.15^{\mathrm{c}}$ & $0.10^{\mathrm{c}}$ & $0.18^{\mathrm{c}}$ & $0.53^{\mathrm{b}}$ & $0.48^{\mathrm{b}}$ & $0.74^{\mathrm{a}}$ \\
\hline Total C (\%) & $1.97^{\mathrm{b}}$ & $3.50^{\mathrm{a}}$ & $2.97^{\mathrm{a}}$ & $1.26^{\mathrm{c}}$ & $2.35^{\mathrm{b}}$ & $2.10^{\mathrm{b}}$ \\
\hline Total N (\%) & $0.17^{\mathrm{c}}$ & $0.21^{\mathrm{a}}$ & $0.20^{\mathrm{ab}}$ & $0.17^{\mathrm{bc}}$ & $0.21^{\mathrm{a}}$ & $0.21^{\mathrm{a}}$ \\
\hline $\mathrm{P}(\mathrm{mg} / \mathrm{kg})$ & $9.7^{\mathrm{c}}$ & $15.0^{\mathrm{c}}$ & $16.8^{\mathrm{c}}$ & $190^{\mathrm{b}}$ & $253^{\mathrm{a}}$ & $258^{\mathrm{a}}$ \\
\hline $\mathrm{K}(\mathrm{mg} / \mathrm{kg})$ & $128^{\mathrm{d}}$ & $222^{\mathrm{c}}$ & $249^{c}$ & $657^{\mathrm{ab}}$ & $587^{\mathrm{b}}$ & $716^{\mathrm{a}}$ \\
\hline $\mathrm{Ca}(\mathrm{mg} / \mathrm{kg})$ & $1360^{\mathrm{d}}$ & $4330^{\mathrm{a}}$ & $2974^{c}$ & $2649^{c}$ & $4029^{a}$ & $3576^{\mathrm{b}}$ \\
\hline $\mathrm{Mg}(\mathrm{mg} / \mathrm{kg})$ & $590^{c}$ & $738^{\mathrm{a}}$ & $693^{\mathrm{ab}}$ & $661^{\mathrm{b}}$ & $674^{\mathrm{b}}$ & $733^{\mathrm{a}}$ \\
\hline \multicolumn{7}{|l|}{$10-20 \mathrm{~cm}$} \\
\hline $\mathrm{pH}$ (water) & $5.12^{\mathrm{c}}$ & $5.48^{\mathrm{b}}$ & $5.08^{c}$ & $6.15^{\mathrm{a}}$ & $6.29^{\mathrm{a}}$ & $6.25^{\mathrm{a}}$ \\
\hline $\mathrm{EC}(\mathrm{dS} / \mathrm{m})$ & $0.72^{\mathrm{c}}$ & $1.30^{\mathrm{ab}}$ & $1.07^{\mathrm{abc}}$ & $0.95^{\mathrm{bc}}$ & $1.28^{\mathrm{ab}}$ & $1.33^{\mathrm{a}}$ \\
\hline $\mathrm{NO}_{3}-\mathrm{N}(\mathrm{mg} / \mathrm{kg})$ & $9.1^{\mathrm{b}}$ & $62.2^{\mathrm{ab}}$ & $85.9^{\mathrm{a}}$ & $12.8^{\mathrm{b}}$ & $23.9^{\mathrm{b}}$ & $10.6^{\mathrm{b}}$ \\
\hline $\mathrm{NH}_{4}-\mathrm{N}(\mathrm{mg} / \mathrm{kg})$ & $0.63^{\mathrm{bc}}$ & $0.40^{\mathrm{c}}$ & $0.53^{b c}$ & $1.25^{\mathrm{ab}}$ & $1.09^{\mathrm{abc}}$ & $1.67^{\mathrm{a}}$ \\
\hline Total C (\%) & $1.93^{\mathrm{b}}$ & $2.40^{\mathrm{a}}$ & $2.03^{\mathrm{b}}$ & $1.30^{\mathrm{c}}$ & $1.40^{\mathrm{c}}$ & $1.45^{\mathrm{c}}$ \\
\hline Total N (\%) & $0.17^{\mathrm{b}}$ & $0.19^{\mathrm{a}}$ & $0.17^{\mathrm{ab}}$ & $0.18^{\mathrm{ab}}$ & $0.18^{\mathrm{ab}}$ & $0.18^{\mathrm{ab}}$ \\
\hline $\mathrm{P}(\mathrm{mg} / \mathrm{kg})$ & $9.8^{\mathrm{c}}$ & $11.7^{\mathrm{c}}$ & $10.9^{c}$ & $200^{\mathrm{b}}$ & $207^{\mathrm{ab}}$ & $214^{\mathrm{a}}$ \\
\hline $\mathrm{K}(\mathrm{mg} / \mathrm{kg})$ & $212^{\mathrm{b}}$ & $273^{\mathrm{b}}$ & $244^{\mathrm{b}}$ & $678^{\mathrm{a}}$ & $555^{\mathrm{a}}$ & $565^{\mathrm{a}}$ \\
\hline $\mathrm{Ca}(\mathrm{mg} / \mathrm{kg})$ & $1447^{\mathrm{d}}$ & $2541^{\mathrm{c}}$ & $1590^{\mathrm{d}}$ & $2660^{\mathrm{bc}}$ & $3096^{\mathrm{a}}$ & $2856^{\mathrm{ab}}$ \\
\hline $\mathrm{Mg}(\mathrm{mg} / \mathrm{kg})$ & $593^{\mathrm{b}}$ & $611^{\mathrm{b}}$ & $688^{\mathrm{a}}$ & $472^{\mathrm{d}}$ & $486^{\mathrm{cd}}$ & $546^{\mathrm{bc}}$ \\
\hline
\end{tabular}

\subsection{Papaya}

\subsubsection{Soil}

Overall, both surface (SBC) and incorporated (IBC) applications of amendments significantly increased soil $\mathrm{pH}, \mathrm{EC}$, total $\mathrm{C}$, total $\mathrm{N}, \mathrm{P}, \mathrm{Ca}$, and $\mathrm{Mg}$ in the $0-10 \mathrm{~cm}$ soil layer at harvest (Table 5). In the 10-20 cm layer, both SBC and IBC significantly increased $\mathrm{EC}, \mathrm{NO}_{3}-\mathrm{N}$, and $\mathrm{Ca}$. In addition, only IBC significantly increased $\mathrm{pH}$ and total $\mathrm{C}$ in the $10-20 \mathrm{~cm}$ layer, and only SBC significantly increased $\mathrm{NH}_{4}-\mathrm{N}, \mathrm{K}$, in the $0-10 \mathrm{~cm}$ and $\mathrm{P}, \mathrm{Mg}$ in the $10-20 \mathrm{~cm}$ layer.

Soil $\mathrm{pH}$ was significantly increased by both IBC and SBC in both soil types in the $0-10 \mathrm{~cm}$ layer. In the Andisol, $\mathrm{pH}$ had significantly increased by 0.45 units for SBC and by 1.05 units for IBC. In the Oxisol, soil $\mathrm{pH}$ was significantly increased by 0.44 units for SBC and 0.45 units for IBC. As found in the Chinese cabbage data, soil $\mathrm{pH}$ was significantly higher in the 10-20 cm layer for the IBC amended Andisol. For soil EC in the 10-20 cm layer, it was significantly higher just with SBC than the unamended Oxisol and was significantly higher just with IBC than the unamended Andisol.

Soil $\mathrm{C}$ was $78 \%$ significantly higher with IBC amendment and 51\% significantly higher with SBC than that in the unamended Andisol in the $0-10 \mathrm{~cm}$ layer (Table 5). The
Oxisol soil C was $87 \%$ significantly higher with IBC and $67 \%$ significantly higher with SBC than that the unamended Oxisol. The SBC increased soil C to the same extent that IBC did, even though the remaining surface amendments were removed before soil analyses. As was found with the Chinese cabbage trial, total soil $\mathrm{C}$ had significantly increased in the 10-20 cm layer of the IBC amendment in the Andisol (24\%) compared to the unamended soil.

Total $\mathrm{N}$ was significantly higher in both the IBC and SBC than that in the unamended soil in the $0-10 \mathrm{~cm}$ layer of the Andisol, and significantly higher in both amendments to the same extent in the Oxisol (Table 5). There was no difference in $\mathrm{NO}_{3}-\mathrm{N}$ concentrations, except for in the $10-20 \mathrm{~cm}$ layer in the Andisol, where SBC significantly increased $\mathrm{NO}_{3}-\mathrm{N}$ ten times compared to the unamended. The only difference in $\mathrm{NH}_{4}-\mathrm{N}$ concentration was a significant increase from the SBC amendment compared to the control in the $0-10 \mathrm{~cm}$ layer of the Oxisol.

Both IBC and SBC amendments significantly increased soil nutrient concentrations of extractable $\mathrm{P}$, and $\mathrm{Ca}$ in the $0-10 \mathrm{~cm}$ layer of the Oxisol, whereas in the Andisol, K, Ca, and $\mathrm{Mg}$ concentrations were significantly higher than that the unamended control (Table 5). The nutrient concentration patterns in the $10-20 \mathrm{~cm}$ were mixed for both soil types. In the Oxisol, $\mathrm{P}$ was $36 \%$ significantly higher in the $\mathrm{SBC}$ and 


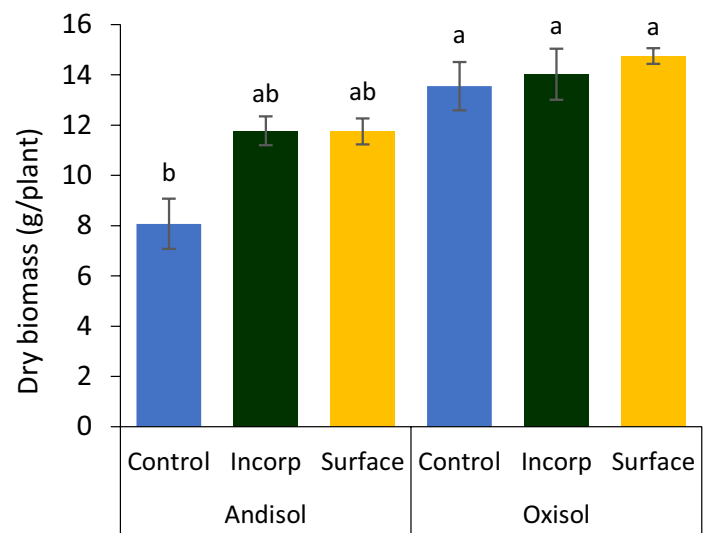

Fig. 3 Plant dry weight biomass (g/plant) of papaya (established November 2017) at 3 months old in Andisol and Oxisol soils for control, incorporated and surface-applied treatments with standard error $(n=4)$ and significance of treatment effect (different letters signify a statistical difference at $p<0.05$ ). When soil data were combined, there was significantly higher plant biomass in the surface-applied amendments than control
$34 \%$ significantly higher in the IBC than that the unamended Oxisol in the $0-10 \mathrm{~cm}$ layer, and $7 \%$ significantly higher in the SBC than that the unamended in the $10-20 \mathrm{~cm}$ layer. Soil $\mathrm{K}$ concentration was significantly higher only in the Andisol 0-10 cm soil layer, by both IBC and SBC. Soil Ca was significantly higher in both IBC and SBC than that the unamended in the Andisol. Only the IBC amendment significantly increased $\mathrm{Ca}$ in the $10-20 \mathrm{~cm}$ soil layer in both soil types.

\subsubsection{Papaya biomass}

Overall, with both soils combined, plant dry biomass was $24 \%$ significantly higher in SBC than that in the unamended soil, but IBC was not statistically different. Plants grown in the Oxisol had 34\% more biomass than those grown in the Andisol. The effects of IBC and SBC were not statistically significant, however, when compared separately for each soil type (Fig. 3).

The soil amendments had only a small impact on the plant nutrient concentration at harvest (Supplementary material 2). Nitrogen in the plants was significantly lower in the IBC than that the unamended in the Andisol. IBC significantly increased plant concentrations of $\mathrm{Ca}$, Fe and $\mathrm{K}$ compared to the unamended soil, but $\mathrm{P}$ and $\mathrm{Mg}$ concentrations were
Table 6 Total plant nutrient uptake (mg/plant) at harvest of papaya for the two soil types $(n=4)$ and significance of treatment effect (different letters signify a statistical difference at $p<0.05$ along each row)

\begin{tabular}{|c|c|c|c|c|c|c|}
\hline & \multicolumn{3}{|l|}{ Andisol } & \multicolumn{3}{|l|}{ Oxisol } \\
\hline & Control & Incorp & Surface & Control & Incorp & Surface \\
\hline $\mathrm{N}$ & $201^{\mathrm{b}}$ & $243^{\mathrm{ab}}$ & $271^{\mathrm{ab}}$ & $262^{\mathrm{ab}}$ & $298^{\mathrm{ab}}$ & $318^{a}$ \\
\hline K & $181^{\mathrm{c}}$ & $308^{b}$ & $256^{\mathrm{bc}}$ & $422^{\mathrm{a}}$ & $486^{\mathrm{a}}$ & $499^{\mathrm{a}}$ \\
\hline $\mathrm{P}$ & $15^{\mathrm{c}}$ & $23^{\mathrm{b}}$ & $18^{\mathrm{bc}}$ & $31^{\mathrm{a}}$ & $37^{\mathrm{a}}$ & $35^{\mathrm{a}}$ \\
\hline $\mathrm{Ca}$ & $110^{\mathrm{c}}$ & $190^{\mathrm{ab}}$ & $145^{\mathrm{bc}}$ & $208^{\mathrm{a}}$ & $244^{\mathrm{a}}$ & $239^{\mathrm{a}}$ \\
\hline $\mathrm{Mg}$ & $101^{\mathrm{ab}}$ & $144^{\mathrm{a}}$ & $146^{\mathrm{a}}$ & $98^{\mathrm{b}}$ & $106^{\mathrm{ab}}$ & $123^{\mathrm{ab}}$ \\
\hline
\end{tabular}

Fig. 4 Root biomass rank of papaya at harvest, in Andisol and Oxisol soils for control, incorporated and surfaceapplied treatments with standard error $(n=4)$ and significance of treatment effect (different letters signify a statistical difference at $p<0.05$ with lowercase letters comparing the $0-10 \mathrm{~cm}$ layer and uppercase letters comparing the 10-20 $\mathrm{cm}$ layer). Each plant's root biomass was visually ranked from 1 to 5 , low to high, after drying and soil removed (Walters and Wehner 1994)

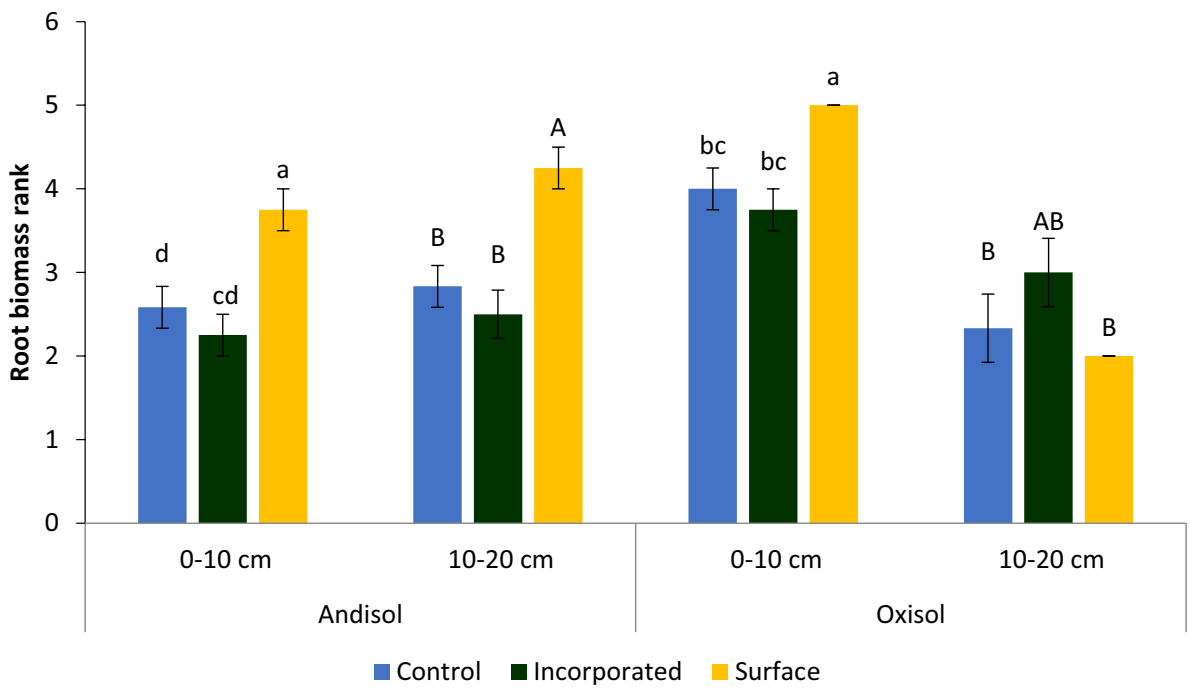


unaffected. Total nutrient uptake, however, was significantly higher in both IBC and SBC for $\mathrm{K}, \mathrm{Ca}$, and $\mathrm{Mg}$, with IBC significantly increasing plant $\mathrm{P}$ content, but not affecting $\mathrm{N}$ (Table 6).

\subsubsection{Papaya roots}

The root distribution of the papayas was very different to that found for the Chinese cabbage in response to the amendments as the majority of the roots were in the $0-10 \mathrm{~cm}$ layer. Overall, in the $0-10 \mathrm{~cm}$ layer, only SBC resulted in significantly higher root biomass than the unamended soil (Fig. 4). In the 10-20 cm layer, both the IBC and SBC resulted in significantly higher root biomass than the unamended soil. The roots had a greater biomass in the $0-10 \mathrm{~cm}$ layer in the Oxisol compared to the Andisol, but there was no difference between the soil types in 10-20 cm layer.

\section{Discussion}

\subsection{Impact of biochar and compost on soil and plants}

Regardless of whether the amendments were incorporated or on the surface, the combination of the wood biochar and chicken manure compost significantly increased soil fertility, and plant and root biomass. Plant biomass yield increases of 14-70\% compared to the mineral fertilised soils were of similar scale to other studies using combined biochar and compost (Agegnehu et al. 2015; Berek et al. 2018; Cao et al. 2018; Liu et al. 2019; Schulz and Glaser 2012). Plants grown in biochar and compost amended soils were deemed more effective at accessing and using nutrients than that the controls (Agegnehu et al. 2016a; Berek et al. 2018; Manolikaki and Diamadopoulos 2019; Schulz and Glaser 2012). This is likely due to the additional nutrients supplied by the amendments, improved nutrient availability from the increased soil $\mathrm{pH}$, increased soil organic matter content, water-holding capacity and reduced nutrient leaching (Agegnehu et al. 2015, 2016b,c; Cao et al. 2018; Ghosh et al. 2015; Liu et al. 2012; Radin et al. 2018). It is suggested that these Hawaiian soil properties improved (and plant biomass increased) due to their initial low fertility, acidic $\mathrm{pH}$ and coarse texture, as the amendments addressed these specific limitations (Jeffery et al. 2017).

Chinese cabbage and papaya biomass increases may be explained by increased nutrient supply and/or retention. The amendments provided 1.7 times (Oxisol) to 2 times (Andisol) the $\mathrm{N}$ more than the mineral fertiliser. They also provided more $\mathrm{P}$ ( 0.75 times) and $\mathrm{K}$ ( 0.79 times) than the fertiliser for the Andisol. The compost component of the combination was more likely to contribute the most available nutrients (Liu et al. 2019; Radin et al. 2018). At harvest, the soil $\mathrm{N}$ was higher in the amended $0-10 \mathrm{~cm}$ soil for the papaya trials, but was not consistent for the Chinese cabbage trials. This may be explained by the longer growing period for the papayas, and the variability experienced in the cabbage trials.

The $\mathrm{NO}_{3}{ }^{-}-\mathrm{N}$ concentrations were double in the amended Oxisol soils for the Chinese cabbage, which may be due to the ability of biochar to reduce nitrate leaching by retaining $\mathrm{N}$ within the biochar pore structure (Agegnehu et al. 2015; Borchard et al. 2019; Nguyen et al. 2017). The amendments had no effect, however, on $\mathrm{NO}_{3}{ }^{-}-\mathrm{N}$ concentrations in the Andisol soil, which may be due to its low-nutrient retention capacity. Borchard et al. (2019) also found that $\mathrm{NO}_{3}{ }^{-}-\mathrm{N}$ concentration was unaffected by biochar addition to coarse or medium textured soil, yet increased in fine soil. They attributed biochar's ability to both reversibly take up and release $\mathrm{NO}_{3}{ }^{-}$, the key to understanding the complexity of $\mathrm{NO}_{3}{ }^{-}$stabilisation and retention pathways.

The increase in soil $\mathrm{pH}$, which was associated with improved nutrient availability, may have contributed to increased plant biomass (Berek et al. 2018; Slavich et al. 2013; Van Zwieten et al. 2015). The increase of 0.4-1.1 pH units found for IBC in the $0-10 \mathrm{~cm}$ layer was anticipated due to the liming effects of biochars (Bass et al. 2016; Berek et al. 2018; Doan et al. 2015; Liu et al. 2012; Radin et al. 2018). The increase in soil $\mathrm{pH}$ after application of an alkaline biochar is thought to be attributed to the biochar's high base cation content, alkalinity and its capacity to decrease exchangeable $\mathrm{Al}$ and $\mathrm{H}$ (Brassard et al. 2019).

It is possible that the higher plant biomass response in the Andisol soil was due to the larger increase in soil $\mathrm{pH}$ [from 5.6 to 6.3 (IBC) and 5.9 (SBC) for cabbage for example], compared with the Oxisol, being closer to 7 (Berek et al. 2018). The acidic Andisol soil was improved by the amendments, which transferred it into the preferred $\mathrm{pH}$ range of the Chinese cabbage (Berek et al. 2018). The soil pH change found in this study is consistent with the significant association between increased soil $\mathrm{pH}$ and plant productivity in the acidic to neutral range by Jeffrey et al. (2011) and especially in the tropical climate (Jeffery et al. 2017).

Most studies have shown that biochar and compost application increased available soil $\mathrm{K}$ due to the addition of $\mathrm{K}$ in an available form (Agegnehu et al. 2015; Radin et al. 2018; Sadegh-Zadeh et al. 2018), however, responses in this study were variable. The papaya trial supported these findings with significant increases in soil K, but only in the Andisol soil. The Chinese cabbage trial, however, had lower soil $\mathrm{K}$ for both treatments and soil layers. This also corresponded to significantly higher plant uptake of K (2-2.5 times) in these treatments than the unamended. It is, therefore, suggested that the reduction in soil $\mathrm{K}$ is due to increased uptake of $\mathrm{K}$ by these plants (Agegnehu et al. 2015; Manolikaki and 
Diamadopoulos 2019). Further to this, the soil layers with reduced $\mathrm{K}$ correspond to higher root biomass in both soil types, and there is also potential for some $\mathrm{K}$ to be held in the roots. Chinese cabbage has a high requirement for $\mathrm{K}$ (Berek et al. 2018; van Averbeke et al. 2007) and it was determined that at harvest, the control plants had insufficient $\mathrm{K}$ concentrations (Jones et al. 1991). The outlier of higher soil K in the $0-10 \mathrm{~cm}$ for the SBC than the control, in the Oxisol, could not be explained by plant response, and is another example of inconsistent $\mathrm{K}$ to biochar (Hossain et al. 2020).

The higher $\mathrm{P}$ in the amended soil increased $\mathrm{P}$ availability and subsequent plant uptake, which was supported by other similar studies (Agegnehu et al. 2016c; Bass et al. 2016; Manolikaki and Diamadopoulos 2019; Van Zwieten et al. 2019). Greater plant $P$ uptake from amended soil was particularly evident in the Andisol, a soil inherently deficient in P (Uehara and Ikawa 2000). As wood-derived biochars (such as the one in this study) have shown little effect on $\mathrm{P}$ availability in soils (Glaser and Lehr 2019), it is likely that the compost has supplied the majority of the available P. The addition of both mineral and organic $\mathrm{P}$ forms in the compost may have allowed microbial mineralisation of organic $\mathrm{P}$ over time to supply plant needs, especially for the papaya plant (da Silva et al. 2019).

The combination of biochar and compost has often proved superior to separate amendments in increasing plant biomass (Al-Omran et al. 2019; Berek et al. 2018; Ghosh et al. 2015; Khorram et al. 2019; Liu et al. 2019; Pandit et al. 2019), which may be influenced by the additive nature of the complementary properties. A mechanism proposed to explain this suggests the formation of nutrient-rich organic coatings that cover the pore surfaces (inner and outer) of biochar particles improves nutrient retention and availability (Hagemann et al. 2017). In addition, evidence of compost adsorption to biochar exists, creating soil-biochar-compost aggregates, which may provide protection from microbial decomposition, and slowing mineralisation (Jien et al. 2018).

\subsection{Surface vs. incorporated amendment application}

The plant biomass in the surface-applied amendment in this study was as great as that found in the incorporated amendment, despite the surface-applied amendments having little contact with the bulk soil. When the soil data were combined, papaya biomass was larger than the control, only in the surface-applied amendment. This was unexpected given that several studies using surface application of biochar with organic matter in perennial subtropical crops reported no or negative effects (Bass et al. 2016; Galanti et al. 2019). The yield response to surface application of biochar alone has also shown to be negligible (Sarauer et al. 2018; Schnell et al. 2012), though there are fewer studies examining this application method. Incorporated compost has performed better than surface applied, with higher yield, higher soil $\mathrm{C}$ and $\mathrm{N}$, and lower bulk density (Cogger et al. 2008; Whatmuff et al. 2018), however, surface application improved water infiltration, and therefore, lowered runoff (Agassi et al. 1998).

The positive response to surface application implies that during the watering process and plant growth, soluble nutrients moved down the profile, and also potentially particles of biochar and/or compost, which were accessible by the roots (Beesley and Dickinson 2011; Cogger et al. 2008; Major et al. 2010; Singh et al. 2015). Some evidence to support this is the $29-57 \%$ increase in total $\mathrm{C}$ in the $0-10 \mathrm{~cm}$ layer for the $\mathrm{SBC}$ compared to the unamended, and a corresponding increase in EC. There was also $12-18 \%$ higher total soil carbon in the $10-20 \mathrm{~cm}$ layer, below where the incorporated amendments were positioned, indicating a movement of soil $\mathrm{C}$ down the profile, as corroborated by others (Haefele et al. 2011; Singh et al. 2015). Given the short time frame of this study, the $\mathrm{C}$ is more likely to predominantly be in the dissolved (DOC) than particulate (POC) form (Major et al. 2010). The increase in $C$ could also be attributed to both an increase in DOC released mainly from the compost and the retention of this DOC by the biochar (Lei et al. 2018).

While both IBC and SBC increased soil $\mathrm{pH}$ compared to the unamended soil in the $0-10 \mathrm{~cm}$ layer, IBC also increased soil $\mathrm{pH}$ in the $10-20 \mathrm{~cm}$ layer. It is inferred, therefore, that the alkaline substances of the biochar were released and moved through the soil profile, increasing exchangeable base cations of the soil (Yuan and Xu 2011). This result may be influenced by the soil type, inherent porosity and charge, used in this pot trial.

The increased root biomass in the surface applied amended soil indicates that an adequate release of surface nutrients into the soil layers occurred, where the root system took advantage of the decomposition of the surface amendments and mineralisation of nutrients from the compost over time (Agassi et al. 1998; Ahmad et al. 2014b; Cogger et al. 2008; Jien et al. 2018). The increased root biomass in the 10-20 cm layer, below the incorporated amendments, also supports the trend found for soil $\mathrm{C}$, soil nutrient and $\mathrm{pH}$ with depth. The increased root growth in soil incorporated with biochar and compost may be due to increased soil porosity and water-holding capacity (Agegnehu et al. 2015; Manolikaki and Diamadopoulos 2019), which would, therefore, allow retention of soluble nutrients in the root zone for longer. Liu et al. (2012) showed that this combination of amendments doubled plant-available water-holding capacity, with biochar the main contributor. A limitation of the current study 
is the lack of soil moisture information over time which may have shed further light on the mechanisms involved. Future work, including field trials in different soil types, should include this factor.

\subsection{Andisol vs. Oxisol}

The two soil types responded differently to the amendments, and the increases in plant and root biomass were higher in the Andisol than in the Oxisol. This may be due to the Andisol's lower initial $\mathrm{pH}, \mathrm{P}, \mathrm{K}$, water-holding capacity and bulk density. The Andisol's high infiltration rate, likely due the pumice content, may have been reduced and retained more moisture than the Oxisol, as biochar and composts have been particularly effective at improving soil properties and crop yield in these coarser soil types (Somerville et al. 2019; Wang et al. 2019). The Andisol pH increase due to the amendments may have also overcome some nutrient availability limitations in the acidic range of the unamended soil (Van Zwieten et al. 2015). The Oxisol, while containing more clay, was highly aggregated, and therefore, also had a high infiltration rate. The presence of increased cations in this amended soil at depth indicated movement over time with irrigation (Radin et al. 2018). The 6-10\% higher water requirement over the growing seasons compared to Andisol emphasises the difference in physical structure, and water retention. The responsiveness to biochar amendment of coarser-textured soils through improved soil aggregate stability and increased plant-available water (Burrell et al. 2016) has helped prioritise the soil types more likely to benefit from this soil amendment.

\section{Conclusion}

The results of this study indicate that the combination of biochar and compost is an effective amendment to increase Chinese cabbage and papaya biomass and improve soil chemical properties, and that surface application is an option for perennial horticulture. There is evidence of downward movement of the amendments possibly in soluble or particulate form, with increased soil $\mathrm{pH}$, total $\mathrm{C}$, extractable $\mathrm{P}$ and $\mathrm{Ca}$ in the layer below application. These changes were found in the $10-20 \mathrm{~cm}$ layer below the incorporated amendment and also in the $0-10 \mathrm{~cm}$ layer below the surface-applied amendment. This is supported by the root distribution patterns in the $0-10$ and $10-20 \mathrm{~cm}$ layers. The results suggest the amendments provided extra nutrients, improved nutrient availability and plant uptake, potentially due to improved soil $\mathrm{pH}$ and increased C. However, this was more apparent in the acidic Andisol than the Oxisol that had a $\mathrm{pH}$ of 6.9. The rate of nutrient addition with these amendments was high, as they provided 1.5-2 times the $\mathrm{N}$ more than the mineral fertilised soil. They also provided extra $\mathrm{P}(0.75$ times) and $\mathrm{K}(0.79$ times) than the fertiliser for the Andisol. Further work to control for nutrient addition from amendments would enable exploration of the physical and biological impacts of these inputs. These pot trial results need to be examined with perennials in field trials over a longer time frame to determine the effectiveness of surface application, given the potential risks of losses due to erosion and other farming practices. Biochar and compost in combination can provide an effective input to both increase crop yield and reduce leaching of land-applied fertilisers to the environment.

Acknowledgements The authors gratefully thank all reviewers for their comments and assistance in improving the manuscript.

Funding The project was funded through Western Sustainable Agriculture Research and Education (SARE), USDA (for NV Hue and A Ahmad).

\section{Compliance with ethical standards}

Conflict of interest The authors declare that they have no conflict of interest.

Consent for publication The corresponding author consents on behalf of all the authors that this is original work and has permission to be published.

Open Access This article is licensed under a Creative Commons Attribution 4.0 International License, which permits use, sharing, adaptation, distribution and reproduction in any medium or format, as long as you give appropriate credit to the original author(s) and the source, provide a link to the Creative Commons licence, and indicate if changes were made. The images or other third party material in this article are included in the article's Creative Commons licence, unless indicated otherwise in a credit line to the material. If material is not included in the article's Creative Commons licence and your intended use is not permitted by statutory regulation or exceeds the permitted use, you will need to obtain permission directly from the copyright holder. To view a copy of this licence, visit http://creativecommons.org/licenses/by/4.0/.

\section{References}

Agassi M, Hadas A, Benyamini Y, Levy GJ, Kautsky L, Avrahamov L, Zhevelev H (1998) Mulching effects of composted MSW on water percolation and compost degradation rate. Compost Sci Util 6:34-41. https://doi.org/10.1080/1065657X.1998.10701929

Agegnehu G, Bird MI, Nelson PN, Bass AM (2015) The ameliorating effects of biochar and compost on soil quality and plant growth on a Ferralsol. Soil Res 53:1-12. https://doi.org/10.1071/SR14118

Agegnehu G, Nelson PN, Bird MI (2016a) The effects of biochar, compost and their mixture and nitrogen fertilizer on yield and nitrogen use efficiency of barley grown on a Nitisol in the highlands of Ethiopia. Sci Total Environ 569-570:869-879

Agegnehu G, Nelson PN, Bird MI (2016b) Crop yield, plant nutrient uptake and soil physicochemical properties under organic soil amendments and nitrogen fertilization on Nitisols. Soil Tillage Res 160:1-13 
Agegnehu G, Bass AM, Nelson PN, Bird MI (2016c) Benefits of biochar, compost and biochar-compost for soil quality, maize yield and greenhouse gas emissions in a tropical agricultural soil. Sci Total Environ 543:295-306

Agegnehu G, Srivastav AK, Bird MI (2017) The role of biochar and biochar-compost in improving soil quality and crop performance: a review. Appl Soil Ecol 119:156-170. https://doi.org/10.1016/j. apsoil.2017.06.008

Ahmad A, Hue NV, Radovich T (2014a) Nitrogen release patterns of some locally made composts and their effects on the growth of Chinese cabbage (Brassica Rapa, Chinensis Group) when used as soil amendments. Compost Sci Utiliz 22:199-206

Ahmad A, Fares A, Hue NV, Safeeq M, Radovich T, Abbas F, Ibrahim M (2014b) Root distribution of sweet corn (Zea mays) as affected by manure types, rates and frequency of applications. J Anim Plant Sci 24:592-599

Ahmad A, Radovich T, Hue NV, Uyeda J, Arakaki A, Cadby J, Paull R, Sugano J, Teves G (2016) Use of organic fertilizers to enhance soil fertility, plant growth and yield in a tropical environment. In: Larramendy M, Soloneski S (eds) Organic fertilizers. From basic concepts to applied outcomes. https:// doi.org/10.5772/62529

Akmal M, Maqbool Z, Khan KS, Hussain Q, Ijaz SS, Iqbal M, Aziz I, Hussain A, Abbas MS, Rafa HU (2019) Integrated use of biochar and compost to improve soil microbial activity, nutrient availability, and plant growth in arid soil. Arab J Geosci 12:232. https ://doi.org/10.1007/s12517-019-4414-0

Al-Omran A, Ibrahim A, Alharbi A (2019) Effects of biochar and compost on growth and yield of sweet pepper under a partial root-zone drying irrigation system. Can J Agric Crops 4:56-76

Bass AM, Bird MI, Kay G, Muirhead B (2016) Soil properties, greenhouse gas emissions and crop yield under compost, biochar and co-composted biochar in two tropical agronomic systems. Sci Total Environ 550:459-470

Beesley L, Dickinson N (2011) Carbon and trace element fluxes in the pore water of an urban soil following greenwaste compost, woody and biochar amendments, inoculated with the earthworm Lumbricus terrestris. Soil Biol Biochem 43:188-196. https://doi. org/10.1016/j.soilbio.2010.09.035

Berek A, Hue NV (2016) Characterization of biochars and their use as an amendment to acid soils. Soil Sci 181:412-426

Berek A, Hue NV, Radovich T, Ahmad AA (2018) Biochars improve nutrient phyto-availability of Hawai'i's highly weathered soils. Agronomy 8:203-221. https://doi.org/10.3390/agronomy8100203

Borchard N, Schirrmann M, Cayuela ML, Kammann C, Wrage-Mönnig N, Estavillo JM, Fuertes-Mendizábal T, Siguah G, Spokas K, Ippolito JA, Novak J (2019) Biochar, soil and land-use interactions that reduce nitrate leaching and $\mathrm{N}_{2} \mathrm{O}$ emissions: a meta-analysis. Sci Total Environ 651:2354-2364. https://doi.org/10.1016/j.scito tenv.2018.10.060

Brassard P, Godbout S, Lévesque V, Palacios JH, Raghavan V, Ahmed A, Hogue R, Jeanne T, Verma M (2019) Biochar for soil amendment. In: Jeguirim M, Limousy L (eds) Char and carbon materials derived from biomass. Production, characterization and applications. Elsevier, Amsterdam, pp 109-146. https://doi.org/10.1016/ B978-0-12-814893-8.00004-3

Burrell LD, Zehetner F, Rampazzo N, Wimmer B, Soja G (2016) Longterm effects of biochar on soil physical properties. Geoderma 282:96-102. https://doi.org/10.1016/j.geoderma.2016.07.019

Cao Y, Gao Y, Qi Y, Li J (2018) Biochar-enhanced composts reduce the potential leaching of nutrients and heavy metals and suppress plant-parasitic nematodes in excessively fertilized cucumber soils. Environ Sci Pollut Res 25:7589-7599

Cogger C, Hummel R, Hart J, Bary A (2008) Soil and Redosier dogwood response to incorporated and surface-applied compost. HortScience 43:2143-2150 da Silva RS, Rodrigues LA, da Silva MG, da Silva BG, Martins MA (2019) Biochar and mucuna increase papaya plant growth and nutrition, as well as soil fertility. Pesq Agropec Trop Goiânia 49:e55210. https://www.agro.ufg.br/pate. ISSN 1983-4063

Di W, Yanfang F, Lihong X, Manqiang L, Bei Y, Feng H, Linzhang Y (2019) Biochar combined with vermicompost increases crop production while reducing ammonia and nitrous oxide emissions from a paddy soil. Pedosphere 29:82-94. https://doi.org/10.1016/ S1002-0160(18)60050-5

Doan TT, Henry-des-Tureaux T, Rumpel C, Janeau J, Jouquet P (2015) Impact of compost, vermicompost and biochar on soil fertility, maize yield and soil erosion in Northern Vietnam: a three year mesocosm experiment. Sci Total Environ 514:147-154

Escobar MEO, Hue NV (2008) Temporal changes of selected chemical properties in three manure-amended soils of Hawaii. Bioresour Technol 99:8649-8654. https://doi.org/10.1016/j.biort ech.2008.04.069

Fischer D, Glaser B (2012) Synergism between compost and biochar for sustainable soil amelioration, management and organic waste. In: Kumer S (ed) Management of organic wastes. In Tech, Rijeka, pp 167-198

Galanti R, Cho A, Ahmad A, Radovich T (2019) Soil amendments and soil profiling impact on macadamia growth and yield performance. HortScience 54:519-527. https://doi.org/10.21273/ HORTSCI13572-18

Ghosh S, Ow FL, Wilson B (2015) Influence of biochar and compost on soil properties and tree growth in a tropical urban environment. Int J Environ Sci Technol 12:1303-1310. https://doi.org/10.1007/ s13762-014-0508-0

Glaser B, Lehr V (2019) Biochar effects on phosphorus availability in agricultural soils: a meta-analysis. Sci Rep 9:9338. https://doi. org/10.1038/s41598-019-45693-Z

Haefele SM, Konboon Y, Wongboon W, Amarante S, Maarifat AA, Pfeiffer EM, Knoblauch C (2011) Effects and fate of biochar from rice residues in rice-based systems. Field Crops Res 121:430-440. https://doi.org/10.1016/j.fcr.2011.01.014

Hagemann N, Joseph S, Schmidt HP, Kammann CI, Harter J, Borch $\mathrm{T}$ et al (2017) Organic coating on biochar explains its nutrient retention and stimulation of soil fertility. Nat Commun 8:1089. https://doi.org/10.1038/s41467-017-01123-0

Hossain MZ, Bahar MM, Sarkar B, Donne SW, Ok YS, Palansooriya KN, Kirkham MB, Chowdhury S, Bolan N (2020) Biochar and its importance on nutrient dynamics in soil and plant. Biochar. https ://doi.org/10.1007/s42773-020-00065-z

Hue NV, Silva JA (2000) Organic soil amendments for sustainable agriculture: organic sources of nitrogen, phosphorus, and potassium. In: Silva JA, Uchida R (eds) Plant nutrient management in Hawaii's soils, approaches for tropical and subtropical agriculture. College of Tropical Agriculture and Human Resources, University of Hawaii at Manoa, Honolulu, pp 133-144

Jeffery S, Abalos D, Prodana M, Bastos AC, van Groenigen JW, Hungate BA, Verheijen F (2017) Biochar boosts tropical but not temperate crop yields. Environ Res Lett 12:053001. https://doi. org/10.1088/1748-9326/aa67bd

Jeffrey S, Verheijen FGA, van der Velde M, Bastos AC (2011) A quantitative review of the effects of biochar application to soils on crop productivity using meta-analysis. Agric Ecosyst Environ 144:175-187

Jien S, Chen W, Ok Y, Awad Y, Liao C (2018) Short-term biochar application induced variations in $\mathrm{C}$ and $\mathrm{N}$ mineralization in a compost-amended tropical soil. Environ Sci Pollut Res $25: 25715-25725$

Jones JB, Wolf B, Mills HA (1991) Plant analysis handbook. A practical sampling, preparation, analysis, and interpretation guide. Micro-Macro Publishing Inc., Athens 
Kammann C, Glaser B, Schmidt HP (2016) Combining biochar and organic amendments. In: Ruysschaert G, Zwar K, Glaser B (eds) Shackley S. Biochar in European soils, Routledge, London pp, pp 136-164

Karhu K, Mattila T, Bergstrom I, Regina K (2011) Biochar addition to agricultural soil increased $\mathrm{CH}_{4}$ uptake and water holding capacity-results from a short-term pilot field study. Agric Ecosyst Environ 140:309-313

Khorram MS, Zhang G, Fatemi A, Kiefer R, Maddah K, Baqar M, Zakaria MP, Li G (2019) Impact of biochar and compost amendment on soil quality, growth and yield of a replanted apple orchard in a 4-year field study. J Sci Food Agric 99:1862-1869

Lehmann J, Rillig M, Thies J, Masiello C, Hockaday W, Crowley D (2011) Biochar effects on soil biota-a review. Soil Biol Biochem 43:1812-1836

Lei Z, Li Q, Song X, Wang W, Zhang Z, Peng C, Tian L (2018) Biochar mitigates dissolved organic carbon loss but does not affect dissolved organic nitrogen leaching loss caused by nitrogen deposition in Moso bamboo plantations. Glob Ecol Conserv 16:e0494. https://doi.org/10.1016/j.gecco.2018.e00494

Liu J, Schulz H, Brandl S, Miehtke H, Huwe B, Glaser B (2012) Shortterm effect of biochar and compost on soil fertility and water status of a Dystric Cambisol in NE Germany under field conditions. J Plant Nutr Soil Sci 175:698-707. https://doi.org/10.1002/ jpln.201100172

Liu B, Cai Z, Zhang Y, Liu G, Luo X, Zheng H (2019) Comparison of efficacies of peanut shell biochar and biochar-based compost on two leafy vegetable productivity in an infertile land. Chemosphere 224:151-161

Major J, Lehmann J, Rondon M, Goodale C (2010) Fate of soil-applied black carbon: downward migration, leaching and soil respiration. Glob Change Biol 16:1366-1379. https://doi.org/10.111 1/j.1365-2486.2009.02044.x

Manolikaki I, Diamadopoulos E (2019) Positive effects of biochar and biochar-compost on maize growth and nutrient availability in two agricultural soils. Commun Soil Sci Plan 50:512-526

McDonald MR, Bakker C, Motior MR (2019) Evaluation of wood biochar and compost soil amendment on cabbage yield and quality. Can J Plant Sci 99:624-638. https://doi.org/10.1139/ cjps-2018-0122

Mehlich A (1984) Mehlich 3 soil test extractant: a modification of Mehlich 2 extractant. Commun Soil Sci Plan 15:1409-1416. https ://doi.org/10.1080/00103628409367568

Nguyen TTN, Xu C-Y, Tahmasbian I, Che R, Xu Z, Zhou X, Wallace HM, Bai SH (2017) Effects of biochar on soil available inorganic nitrogen: a review and meta-analysis. Geoderma 288:79-96. https ://doi.org/10.1016/j.geoderma.2016.11.004

Novak JM, Ippolito JA, Watts D, Sigua GC, Ducey TF, Johnson MG (2019) Biochar compost blends facilitate switchgrass growth in mine soils by reducing $\mathrm{Cd}$ and $\mathrm{Zn}$ bioavailability. Biochar 1:97114. https://doi.org/10.1007/s42773-019-00004-7

Oo AZ, Gonai T, Sudo S, Win KT, Shibata A (2018) Surface application of fertilizers and residue biochar on $\mathrm{N} 2 \mathrm{O}$ emission from Japanese pear orchard soil. Plant Soil Environ 64:597-604

Palansooriya KN, Wong J, Hashimoto Y, Huang L, Rinklebe J, Chang SX, Bolan N, Wang H, Ok Y (2019) Response of microbial communities to biochar-amended soils: a critical review. Biochar 1:3-22. https://doi.org/10.1007/s42773-019-00009-2

Pandit NR, Schmidt HP, Mulder J, Hale SE, Husson O, Cornelissen G (2019) Nutrient effect of various composting methods with and without biochar on soil fertility and maize growth. Arch Agron Soil Sci 66:250-265. https://doi.org/10.1080/03650 340.2019.1610168

Paulin B, O'Malley P (2008) Compost production and use in horticulture. Department of Agriculture and Food, Western Australia, Perth. Bulletin 4746. http://researchlibrary.agric.wa.gov.au/cgi/ viewcontent.cgi? article $=1197 \&$ context $=$ bulletins. Accessed 2 Feb 2020

Radin R, Bakar RA, Ishak CF, Ahmad SH, Tsong LC (2018) Biocharcompost mixture as amendment for improvement of polybaggrowing media and oil palm seedlings at main nursery stage. Int $\mathbf{J}$ Recycl Org Waste Agric 7:11-23. https://doi.org/10.1007/s4009 3-017-0185-3

Rumpel C, Ba A, Darboux F, Chaplot V, Planchon O (2009) Erosion budget and process selectivity of black carbon at meter scale. Geoderma 154:131-137. https://doi.org/10.1016/j.geode rma.2009.10.006

Rumpel C, Leifeld J, Santín C, Doerr SH (2015) Movement of biochar in the environment. In: Lehmann JL, Joseph S (eds) Biochar for environmental management. Science, technology and implementation, 2nd edn. Taylor \& Francis, New York, pp 283-299

Sadegh-Zadeh F, Tolekolai SF, Bahmanyar MA, Emadi M (2018) Application of biochar and compost for enhancement of rice (Oryza sativa L.) grain yield in calcareous sandy soil. Commun Soil Sci Plant Anal 49:552-566

Sánchez-Monedero MA, Cayuela ML, Sánchez-García M, Vandecasteele B, D’Hose T, López G, Martínez-Gaitán C, Kuikman PJ, Sinicco T, Mondini C (2019) Agronomic evaluation of biochar, compost and biochar-blended compost across different cropping systems: Perspective from the European Project FERTIPLUS. Agronomy 9:225-244. https://doi.org/10.3390/agronomy9050225

Sarauer JL, Page-Dumroese DS, Coleman MD (2018) Soil greenhouse gas, carbon content, and tree growth response to biochar amendment in western United States forests. GCB Bioenergy 11:660-671

Schnell RW, Vietor DM, Provin TL, Munster CL, Capareda S (2012) Capacity of biochar application to maintain energy crop productivity: soil chemistry, sorghum growth, and runoff water quality effects. J Environ Qual 41:1044-1051. https://doi.org/10.2134/ jeq2011.0077 schn

Schulz H, Glaser B (2012) Effects of biochar compared to organic and inorganic fertilizers on soil quality and plant growth in a greenhouse experiment. J Plant Nutr Soil Sci 175:410-422. https://doi. org/10.1002/jpln.201100143

Singh BP, Fang Y, Boersma M, Collins D, Van Zwieten L, Macdonald LM (2015) In situ persistence and migration of biochar carbon and its impact on native carbon emission in contrasting soils under managed temperate pastures. PLoS ONE 10:e0141560. https://doi. org/10.1371/journal.pone.0141560

Slavich P, Sinclair K, Morris S, Kimber S, Downie A, Van Zwieten L (2013) Contrasting effects of manure and green waste biochars on the properties of an acidic Ferralsol and productivity of a subtropical pasture. Plant Soil 366:213-227

Somerville PD, Farrell C, May PB, Livesley SJ (2019) Tree water use strategies and soil type determine growth responses to biochar and compost organic amendments. Soil Till Res 192:12-21. https:// doi.org/10.1016/j.still.2019.04.023

Sun F, Lu S (2014) Biochars improve aggregate stability, water retention, and pore-space properties of clayey soil. J Plant Nutr Soil Sci 177:26-33. https://doi.org/10.1002/jpln.201200639

Uehara G, Ikawa H (2000) Use of information from soil surveys and classification. In: Silva JA, Uchida R (eds) Plant nutrient management in Hawaii's soils, approaches for tropical and subtropical agriculture. University of Hawaii at Mano, College of Tropical Agriculture and Human Resources, Honolulu, pp 67-77

Van Averbeke W, Juma KA, Tshikalange TE (2007) Yield response of African leafy vegetables to nitrogen, phosphorus and potassium: The case of Brassica rapa L. subsp. chinensis and Solanum retroflexum Dun. Water SA 33:355-361. https://doi.org/10.4314/ wsa.v33i3.180595

Van Zwieten L, Kimber S, Morris S, Chan KY, Downie A, Rust J, Joseph S, Cowie A (2010) Effects of biochar from slow 
pyrolysis of papermill waste on agronomic performance and soil fertility. Plant Soil 327:235-246. https://doi.org/10.1007/s1110 4-009-0050-x

Van Zwieten L, Rose T, Herridge D, Kimber S, Rust J, Cowie A, Morris S (2015) Enhanced biological N2 fixation and yield of faba bean (Vicia faba L.) in an acid soil following biochar addition: dissection of causal mechanisms. Plant Soil 395:7-20. https://doi. org/10.1007/s11104-015-2427-3

Van Zwieten L, Kimber S, Morris S, Macdonald LM, Rust J, Petty S, Joseph S, Rose T (2019) Biochar improves dairy pasture yields by alleviating $\mathrm{P}$ and $\mathrm{K}$ constraints with no influence on soil respiration or $\mathrm{N}_{2} \mathrm{O}$ emissions. Biochar 1:115-126. https://doi. org/10.1007/s42773-019-00005-6

Walters SA, Wehner TC (1994) Evaluation of the U.S. cucumber germplasm collection for root size using a subjective rating technique. Euphytica 79:39-43. https://doi.org/10.1007/BF00023574

Wang C, Walter MT, Parlange JY (2013) Modeling simple experiments of biochar erosion from soil. J Hydrol 499:140-145. https://doi. org/10.1016/j.jhydrol.2013.06.055
Wang D, Li C, Parikh SJ, Scow KM (2019) Impact of biochar on water retention of two agricultural soils - a multi-scale analysis. Geoderma 340:185-191. https://doi.org/10.1016/j.geode rma.2019.01.012

Whatmuff M, Dougherty W, Kimber S, Collins D (2018) Land application of mixed waste organic outputs provide agronomic benefits but also presents environmental risk. In: Proceedings Australian Soil Science Conference, Canberra, Australia

Yuan JH, Xu RK (2011) The amelioration effects of low temperature biochar generated from nine crop residues on an acidic Ultisol. Soil Use Manag 27:110-115

Zheng H, Wang Z, Deng X, Herbert S, Xing B (2013) Impacts of adding biochar on nitrogen retention and bioavailability in agricultural soil. Geoderma 206:32-39. https://doi.org/10.1016/j.geode rma.2013.04.018 